$$
1-\operatorname{Ag} 8^{\prime}, 3 \cdot 418
$$

\title{
The European Red Mite And Its Control
}

\author{
Philip Garman and J. F. Townsemd
}

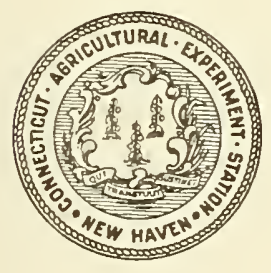

Uomenetiont

Agrimultural Firpreximent Station

Areut Tiguen 
Digitized by the Internet Archive in 2011 with funding from

LYRASIS members and Sloan Foundation 


\section{CONTENTS}

\section{THE EUROPEAN RED MITE AND ITS CONTROL}

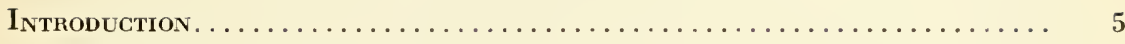

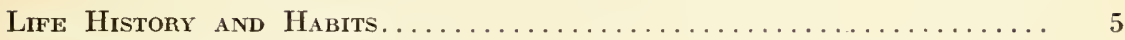

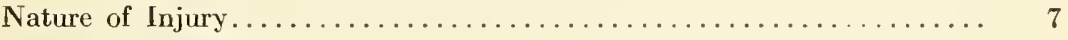

Means of Dispersal............................... 7

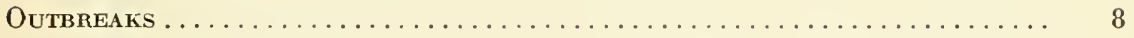

Causes............................................. 8

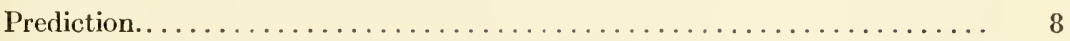

Conditions Affecting Development...................... 9

Weather Conditions Unfavorable to Development............... 9

Enemy Predators or Natural Enemies..................... 9

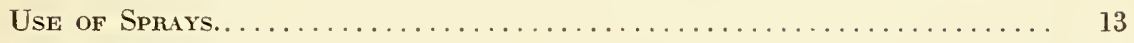

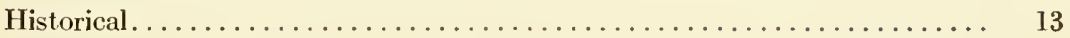

Experimental Results and Field Observations................. 15

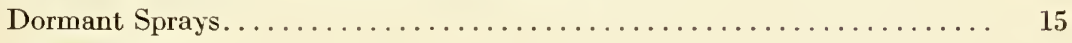

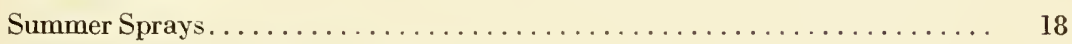

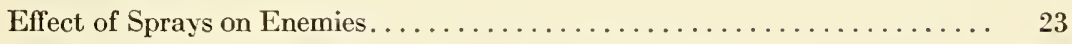

Discussion of Problems Connected with Summer Control............. 27

Occurrence and Control on Peaches and Plums................ 27

Tests of Different Control Schedules.................... 28

Suggestions to Growers............................. 32

Partial Bibliography. . . . . . . . . . . $\ldots \ldots \ldots \ldots \ldots \ldots \ldots \ldots \ldots \ldots \ldots \ldots$ 


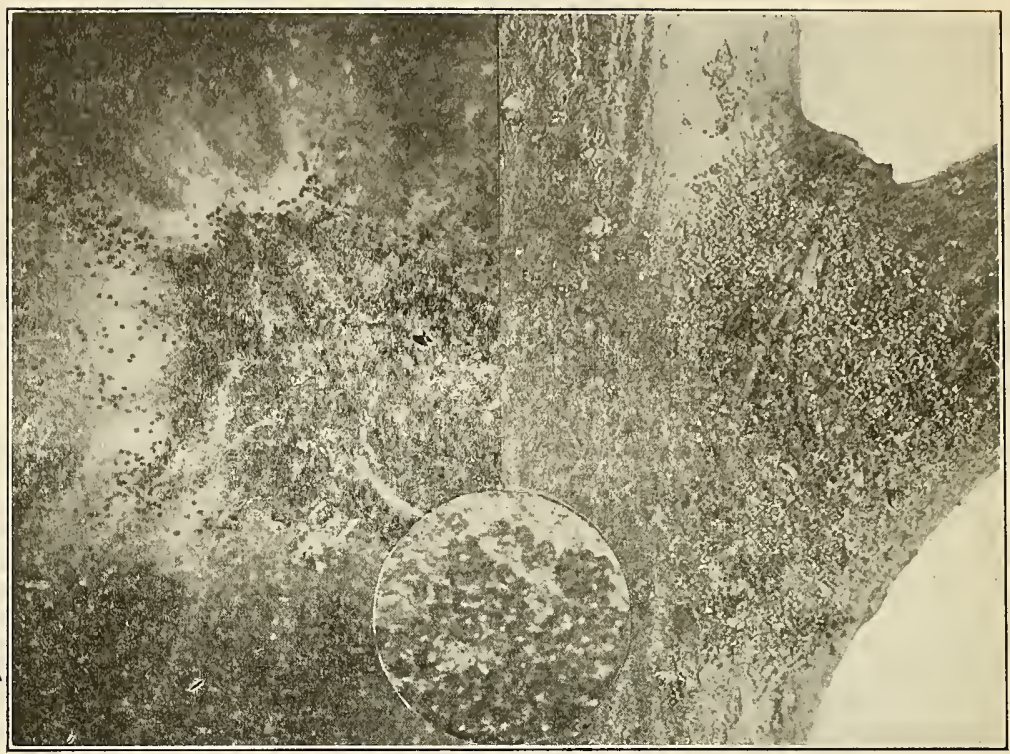

Figure 1. Eggs on calyx end of apple, and on twig, three times enlarged. Insert: same from twig, enlarged about ten times.

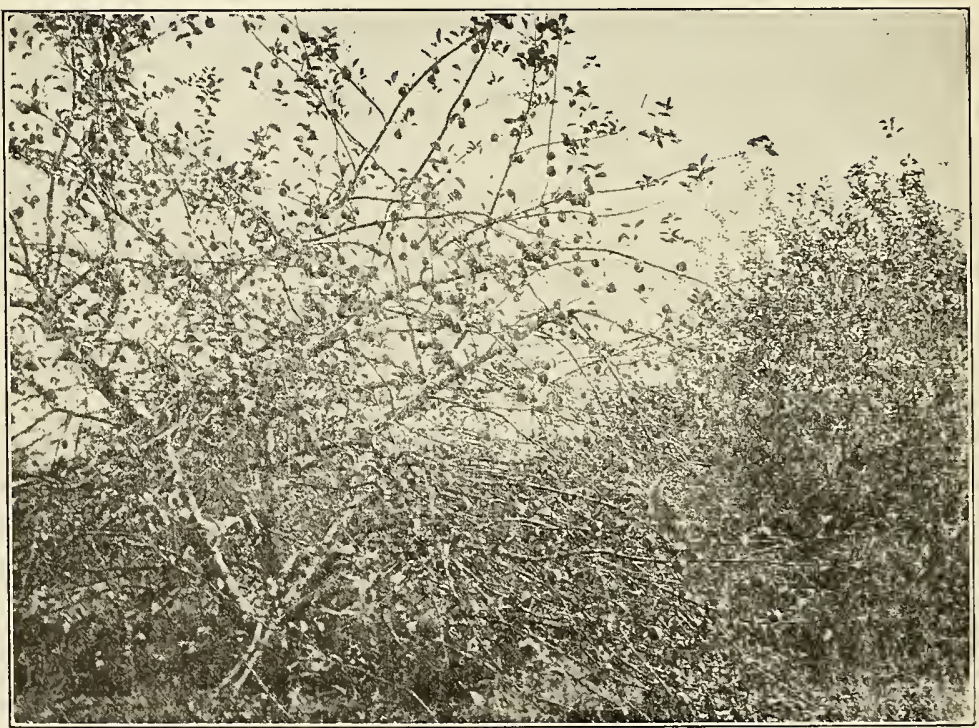

Figure 2. Infested apple tree which has lost much foliage from attacks of the mite. 


\title{
The European Red Mite
}

\section{And Its Control}

\author{
Philip Garman and J. F. Townsend
}

The European red mite first attracted attention in Connecticut in 1920.

Since then it has appeared from time to time, sometimes doing serious damage, but always a source of worry to growers. From 1925 to 1930 it appeared only occasionally, but from 1930 to 1936 it became more abundant, possibly due to dry summers and cold winters or to changing practices on the part of the grower.

Our first experience with the mite was in a large orchard in Branford, where a block of Baldwin trees was seriously affected. At the time of this outbreak, lime sulfur fungicides were being used almost entirely and the spraying was done with a pilot rod from the ground. Investigations indicated better kills for the eggs with dormant oil sprays, which were put into use with gratifying results, merely substituting oil for the delayed dormant lime sulfur. Other growers followed suit with good success, but sometimes with a return of the trouble when it could be afforded least. Investigations in Connecticut during the last three years have been directed towards discovering the cause or causes of these failures.

\section{LIFE HISTORY AND HABITS}

The mite passes the winter in the egg stage on the twigs and bark of the tree. The eggs begin to hatch about the time the apple buds are pink and continue for several weeks. After hatching, the mites build up in population and may become abundant enough by the end of June to make the foliage brown. From that time on, during the season, five or more generations may follow in rapid succession until the vitality of the tree is greatly lowered. Then the mites may move on to more succulent trees, abandoning those first infested. As a result, trees bronzed thoroughly during June and July may not have enough winter eggs to be noticed, whereas those remaining green until late in the season may carry a complete stock of winter eggs and the limbs may be red in color from their abundance. The migrating habits and the general uncertainty regarding enemy populations cause outbreaks to be erratic, appearing in certain portions of the orchard one year and in different portions the next. These facts make practical controls difficult unless close watch is kept on the trees themselves. 


\section{Red Mite Egg Abundance Graham Orchard 1936}
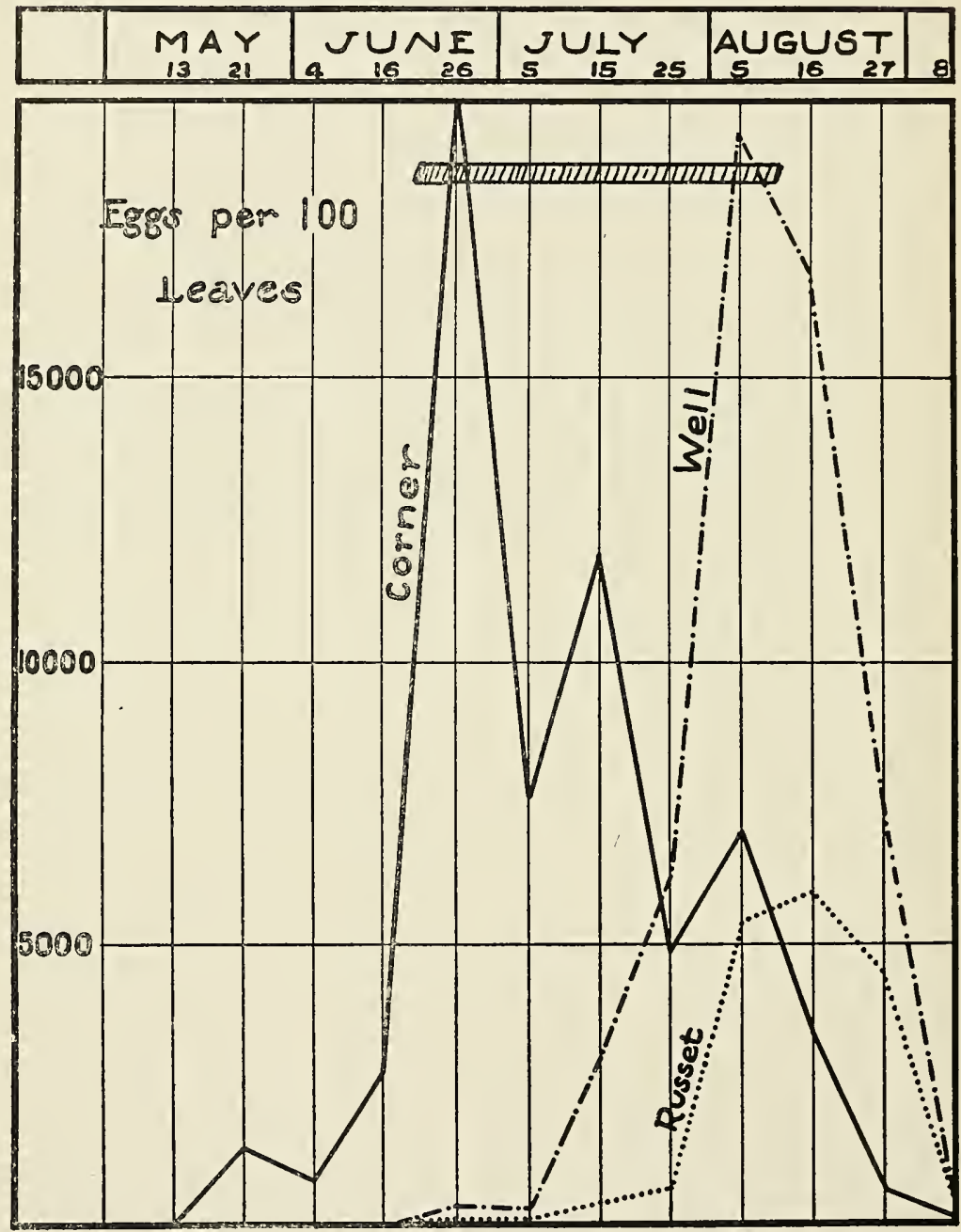

Figure 3. Chart showing results of mite sprays.

Corner lot. Dormant, lime sulfur; summer, dry lime sulfur, derris.

_. Well lot. Dormant, flotation sulfur; summer, flotation sulfur.

.... Russet lot. Dormant, oil; summer, lime sulfur to calyx, then flotation sulfur. [IIIIII Time when summer sprays may be successfully applied. 
The period from the date of hatch until the first adult mites appear is about two weeks and extends from pink to calyx stages. At this time infestations may seem to be limited to a portion of the tree, but after adults begin to appear on the foliage, there is a tendency to wander and scatter to other portions or neighboring trees, so that the infestation becomes more general. Summer egg abundance appears to vary from month to month, though counts in 1936 and 1938 indicate only one real peak of abundance despite the many generations that may occur. (Fig. 3.)

\section{Nature of the Injury}

Injury by the European red mite consists of brown foliage, leaf drop (Fig. 2), and small fruit with poor color. The injury in some cases is indefinite and can only be seen in the brown or bronzed foliage. Severe infestations early in the season are thought to influence the set of fruit for the following year and should be avoided if possible. Late infestations in August and September do not cause much damage because the leares have largely completed their functions for the season. At that time they can probably be disregarded as far as injury to the current crop is concerned, although the possibility of earlier infestations the following year should not be overlooked. In many orchards, however, mites never become abundant enough to cause injury of economic importance, and the damage, unless browning is very marked, cannot be compared with damage from apple maggot, scab or curculio.

The brown color of infested trees in an orchard can sometimes be seen for considerable distances. As distinguished from leafhopper damage to the leaves, the injury from the red mite consists of a much finer spotting or stippling and much less of the chlorophyll or green color is removed. The leaf usually turns brown instead of white and the general brown color of the tree itself is a distinguishing character.

The European red mite infests apple, cherry, peach, and plum in Connecticut and has been reported from other states and countries to infest pear and raspberry. It has also been found in Connecticut on elm and roses.

\section{Means of Dispersal}

Mites are carried from one tree to another largely by wind currents. The mites themselves readily crawl from part to part of the tree. Other means of dispersal, such as transportation on birds, are probably of minor importance. Apples and apple stocks infested with eggs are easily carried from one locality to another, which may account for the almost cosmopolitan distribution. 


\section{OUTBREAKS}

\section{Causes}

Factors commonly supposed to induce outbreaks are as follows:

1. Dry periods in midsummer.

2. Crowded trees.

3. Poor soil, or trees in poor growing condition. ${ }^{2}$

4. Absence of natural enemies.

5. The variety (Baldwin and Delicious most affected in Connecticut).

6. The nature of the spray. Sulfurs, Bordeaux mixture and oils containing tar oil have been shown to influence outbreaks.

Of the causes mentioned, Nos. 2, 3, and 6 can be remedied perhaps more easily than the others. Studies indicate that No. 4 is dependent largely on No. 6. Hence, all except Nos. 1 and 5 are directly or indirectly under the control of the orchardist. The varieties planted are, of course, in the hands of the grower but depend largely on popular demand for the fruit.

\section{Prediction of Outbreaks}

As already stated, outbreaks of the European red mite are frequently erratic. They may occur where there is an abundance of eggs or where there are relatively few. After a bad infestation there is good reason to believe that there will be few mites the following year in places where the infestation was most severe the previous summer. Trees surrounding the spots where bronzing occurred the preceding year will in all probability be heavily coated with eggs and form the centers of new outbreaks. Inspection of the trees at pruning time should reveal the whereabouts of the infested portions. It has been stated that trees carrying the heaviest infestations of winter eggs are likely to be immune, but it seems dangerous to assume that this will be true even in a minority of cases. In our experience, infestations have usually started earlier in trees where there were abundant eggs and have sometimes reached dangerous numbers in June. The exact number of eggs needed to produce an infestation is uncertain, but we know that a population of three to six red eggs per 15-inch twig was enough to cause an outbreak in one orchard during 1938. It has been stated by New Zealand workers (4) that overwintering eggs lack vitality if laid early in the summer, but are more vigorous if laid in early fall during cooler weather. These same conditions probably hold true in Connecticut but are not so noticeable here as in New Zealand.

\footnotetext{
1 Such trees frequently show the infestation sooner, although actually they may not be infested any earlier than other trees in the vicinity.
} 


\section{CONDITIONS AFFECTING DEVELOPMENT}

\section{Unfavorable Weather Conditions}

There is some variation in the percentage of hatch, as may be noted in the checks of various experiments. This may be due to adverse weather conditions but the exact nature of the conditions affecting the hatch is not known. It is, of course, influenced by predators on the trees over the winter.

Removal of eggs by ice storms has been observed in a few cases. It appears to be necessary for the ice to crack away from the bark carrying the eggs with it, and is an entirely mechanical action. Ordinary cold has no effect on the egg, according to our observations.

Heavy dashing rains remove mites from the trees during the summer and may afford a temporary check to their development. A long continued rainy spell also serves as a temporary check, and a long cloudy, damp, rainy spell probably has more influence on the mite than any other weather condition.

\section{Enemy Predators or Natural Enemies}

Small insects and mites prey upon the European red mite. The most common and effective are other species of mites, several thrips and a black ladybeetle, much smaller than the ones feeding on aphids (Fig. 5). In addition, we have a small Anthocorid bug, Orius insidiosus Say, and a number of small lacewing flies. Observations in Nova Scotia (11) and our own in Connecticut during 1936 and 1937 indicate that the mite ${ }^{1}$, related to the red mite, is the most common enemy during midsummer in many orchards. From counts on infested and uninfested trees in 1937, contrary to earlier beliefs, it appeared to be doing a good job of holding the European red mite to reasonable numbers. This natural enemy was apparently so effective in 1936 that unsprayed trees surrounded on three sides by infested ones remained green in color during the growing season in spite of absence of other enemies. It is frequently present in commercial orchards free of red mites and probably feeds on other species of mites when no red mites are present. However, the remaining enemies (see list on page 13) must also be given credit for reducing the number of red mites, especially where severe outbreaks occur, for they have been effective in situations where no mites were seen. Thrips and ladybeetles are frequently abundant enough during such outbreaks to do considerable good. Adult thrips are more abundant in spring but nymphs may be observed at work throughout the summer. Ladybeetles are more abundant in August and September than at other times although their larvae may be seen at different periods.

Life histories of the various enemies have not been studied extensively. The ladybeetle, Stethorus punctum LeConte, passes the winter in the adult stage. According to our observations, eggs are laid in June, July or A ugust and there is probably only one generation a year. The larvae feed on the mites throughout July and the adults appear again sometime in August. Hibernation occurs under the bark of the trunk or other favorable location.

1 Lasioseius (Seius, Seiulus) pomi Parrott or related species. ${ }_{5}^{5}$ The older name Seius is used throughout the text. It should probably be replaced by Lasioseius. 
Thrips have been found on the bark during winter. They hibernate generally in the adult stage and appear on the leaves early in spring. The nymphs may be seen during the summer on the leaves. The number of generations is not known with certainty.
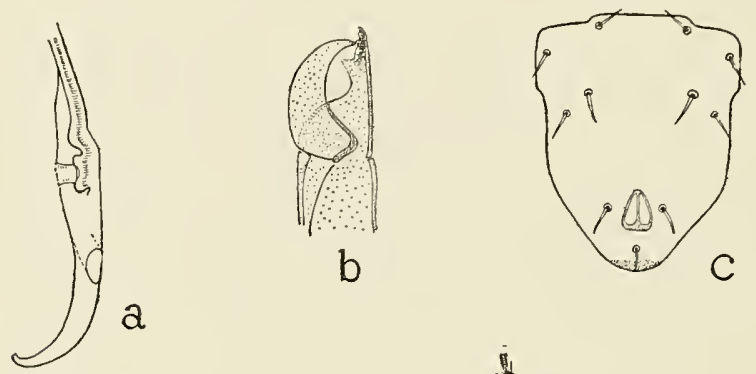

a
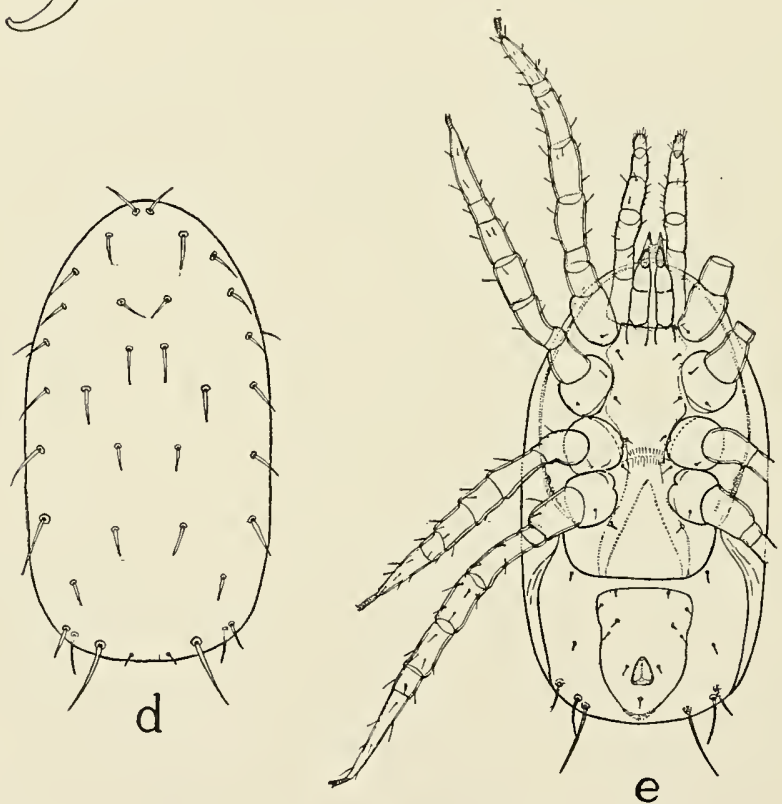

Figure 4. Structural details of Seius species found frequently on apple leaves in Connecticut. Adult female, greatly enlarged. a. Tip of peritreme opposite fourth pair of legs. b. Mandibles. c. Ventral plate same as shown in e but enlarged more. d. Pattern of the dorsal setae. e. Ventral aspect showing plates and setae.

Seius species (mite predators), Fig. 4, pass the winter in the adult stage and mature females with eggs are common on the leaves (Table 1) during July. Mature females have been collected in May, June,' July, August and September. It is possible that several generations occur in a 
single season, the same as for the European red mite. Hibernation occurs on the outer twigs or branches. Owing to the lack of uniformity in descriptions of the species of Seius pomi Parrott by different workers, it has so far not been possible to identify our common species specifically and therefore the detailed drawing of an adult female is given (Fig. 4).

Table 1. Abundance of Adult Females of Seius sp. from Collections in 1937

\begin{tabular}{|c|c|c|c|c|c|c|c|c|c|}
\hline Date & & $\begin{array}{c}\text { Location } \\
\text { on } \\
\text { tree }\end{array}$ & Locality & $\begin{array}{l}\text { Total } \\
\text { mites }\end{array}$ & Small & Medium & $\begin{array}{l}\text { "Full } \\
\text { grown", } \\
(?)\end{array}$ & $\begin{array}{l}\text { No } \\
\text { with } \\
\text { eggs }\end{array}$ & $\begin{array}{l}\% \text { "full } \\
\text { grown" mites } \\
\text { with eggs }\end{array}$ \\
\hline Feb. & $\begin{array}{l}4 \\
7\end{array}$ & $\begin{array}{l}\text { Bark } \\
\text { Bark }\end{array}$ & $\begin{array}{l}\text { Hamden } \\
\text { New Haven }\end{array}$ & $\begin{array}{l}9 \\
1\end{array}$ & $\begin{array}{l}\ldots \\
\ldots\end{array}$ & $\begin{array}{l}\cdots \\
\cdots\end{array}$ & $\begin{array}{l}9 \\
1\end{array}$ & $\begin{array}{l}0 \\
0\end{array}$ & $\begin{array}{l}0 \\
0\end{array}$ \\
\hline $\begin{array}{l}\text { Apr. } \\
\qquad \begin{array}{r}1 \\
1 \\
2\end{array}\end{array}$ & $\begin{array}{r}5 \\
7 \\
10 \\
13 \\
28\end{array}$ & $\begin{array}{l}\text { Bark } \\
\text { Bark } \\
\text { Bark } \\
\text { Bark }\end{array}$ & $\begin{array}{l}\text { Hamden } \\
\text { Hamden } \\
\text { Hamden } \\
\text { Hamden } \\
\text { Hamden }\end{array}$ & $\begin{array}{r}1 \\
3 \\
20 \\
3 \\
\cdots\end{array}$ & $\begin{array}{l}\cdots \\
\cdots \\
\cdots \\
\cdots\end{array}$ & $\begin{array}{l}\cdots \\
\cdots \\
\cdots \\
\cdots \\
\cdots\end{array}$ & $\begin{array}{c}1 \\
10 \\
3 \\
3\end{array}$ & $\begin{array}{l}0 \\
0 \\
0 \\
0 \\
0\end{array}$ & $\begin{array}{l}\dddot{0} \\
\cdots \\
\ddot{0}\end{array}$ \\
\hline May & $\begin{array}{r}5 \\
8 \\
9 \\
12 \\
14 \\
17 \\
17 \\
24\end{array}$ & $\begin{array}{l}\text { Bark (?) } \\
\text { Twigs } \\
\text { Spurs } \\
\text { Bark (?) } \\
\text { Spurs } \\
\text { Leaves } \\
\text { Spurs } \\
\text { Bark } \\
\text { Leaves }\end{array}$ & $\begin{array}{l}\text { Hamden } \\
\text { Hamden } \\
\text { Hamden } \\
\text { Hamden } \\
\text { Hamden } \\
\text { Hamden } \\
\text { Hamden } \\
\text { Hamden } \\
\text { Hamden } \\
\text { Hamden }\end{array}$ & $\begin{array}{r}16 \\
3 \\
24 \\
8 \\
4 \\
12 \\
16 \\
14 \\
1 \\
20\end{array}$ & $\begin{array}{l}\ldots \\
\cdots \\
\cdots \\
\cdots \\
\cdots \\
\cdots \\
\cdots \\
\cdots\end{array}$ & $\begin{array}{r}\cdots \\
22 \\
7 \\
\ddot{3} \\
\cdots \\
\cdots \\
\cdots\end{array}$ & $\begin{array}{r}3 \\
2 \\
1 \\
4 \\
9 \\
16 \\
11 \\
1 \\
17\end{array}$ & $\begin{array}{r}0 \\
0 \\
1 \\
0 \\
3 \\
3 \\
11 \\
9 \\
1 \\
9\end{array}$ & $\begin{array}{r}33 \\
69 \\
82 \\
100 \\
52\end{array}$ \\
\hline $\begin{array}{l}\text { June } \\
\\
\begin{array}{r}1 \\
1 \\
1 \\
1 \\
1 \\
1 \\
2\end{array}\end{array}$ & $\begin{array}{l}1 \\
7 \\
10 \\
10 \\
10 \\
14 \\
17 \\
19 \\
25\end{array}$ & $\begin{array}{l}\text { Leaves } \\
\text { Leaves } \\
\text { Leaves } \\
\text { Bark } \\
\text { Leaves } \\
\text { Leaves } \\
\text { Leaves } \\
\text { Leaves } \\
\text { Leaves }\end{array}$ & $\begin{array}{l}\text { Hamden } \\
\text { Hamden } \\
\text { Hamden } \\
\text { Hamden } \\
\text { Cheshire } \\
\text { Lebanon } \\
\text { Hamden } \\
\text { Hamiden } \\
\text { Cheshire }\end{array}$ & $\begin{array}{r}3 \\
92 \\
21 \\
2 \\
4 \\
2 \\
34 \\
5 \\
10\end{array}$ & $\begin{array}{l}\cdots \\
\cdots \\
\cdots \\
\cdots \\
\cdots \\
\ldots \\
\cdots \\
\cdots\end{array}$ & $\begin{array}{l}\ldots \\
\cdots \\
\cdots \\
3 \\
i 2 \\
\cdots \\
\ldots\end{array}$ & $\begin{array}{r}3 \\
24 \\
15 \\
2 \\
1 \\
2 \\
22 \\
2 \\
1 \\
7\end{array}$ & $\begin{array}{r}2 \\
4 \\
1 \\
1 \\
1 \\
2 \\
20 \\
1 \\
1\end{array}$ & $\begin{array}{r}66 \\
17 \\
90 \\
50 \\
100 \\
100 \\
91 \\
100 \\
14\end{array}$ \\
\hline July & $\begin{array}{r}8 \\
8 \\
21 \\
22 \\
23\end{array}$ & $\begin{array}{l}\text { Leaves } \\
\text { Leaves } \\
\text { Leaves } \\
\text { Leaves } \\
\text { Leaves }\end{array}$ & $\begin{array}{l}\text { Hamden } \\
\text { Hamden } \\
\text { Hamden } \\
\text { Hamden } \\
\text { Hamden }\end{array}$ & $\begin{array}{r}30 \\
45 \\
120 \\
23 \\
1\end{array}$ & $\begin{array}{l}\frac{1}{7} \\
36 \\
\cdots \\
\therefore\end{array}$ & $\begin{array}{l}11 \\
21 \\
31 \\
\cdots \\
\cdots\end{array}$ & $\begin{array}{l}15 \\
17 \\
43 \\
\dddot{1}\end{array}$ & $\begin{array}{l}6 \\
4 \\
6 \\
2 \\
1\end{array}$ & $\begin{array}{l}40 \\
24 \\
14 \\
\dot{5} 0\end{array}$ \\
\hline Aug. & 3 & Leaves & Hamden & 30 & 5 & 8 & 17 & 1 & 6 \\
\hline $\begin{array}{r}\text { Sept. } \\
1 \\
1\end{array}$ & $\begin{array}{r}3 \\
15 \\
17\end{array}$ & $\begin{array}{l}\text { Leaves } \\
\text { Leaves } \\
\text { Leaves }\end{array}$ & $\begin{array}{l}\text { Hamden } \\
\text { Farmington } \\
\text { Guilford }\end{array}$ & $\begin{array}{l}5 \\
5 \\
6\end{array}$ & $\begin{array}{l}\cdots \\
\cdots\end{array}$ & $\begin{array}{l}. \\
\cdots\end{array}$ & $\begin{array}{l}3 \\
1 \\
\cdots\end{array}$ & $\begin{array}{l}0 \\
0 \\
1\end{array}$ & $\begin{array}{l}0 \\
0 \\
1\end{array}$ \\
\hline Oct. 1 & $\begin{array}{r}10 \\
3 \\
25 \\
25\end{array}$ & $\begin{array}{l}\text { Leaves } \\
\text { Leaves } \\
\text { Twigs } \\
\text { Bark }\end{array}$ & $\begin{array}{l}\text { Cheshire } \\
\text { New Haven } \\
\text { Hamden } \\
\text { Hamden }\end{array}$ & $\begin{array}{r}5 \\
5 \\
11 \\
2\end{array}$ & $\begin{array}{l}\cdots \\
\cdots \\
\ldots\end{array}$ & $\begin{array}{l}\ldots \\
\cdots \\
\cdots\end{array}$ & $\begin{array}{r}2 \\
1 \\
11 \\
\ldots\end{array}$ & $\begin{array}{l}0 \\
0 \\
0 \\
0\end{array}$ & $\begin{array}{l}0 \\
0 \\
0 \\
0\end{array}$ \\
\hline
\end{tabular}




\section{Relative Importance of the Different Enemies}

Seius mites and Stethorus ladybeetles are probably the most important of the enemies mentioned. Under favorable conditions both apparently are able to check infestations. Thrips are next in importance, with probably Orius (Triphleps) a close fourth.

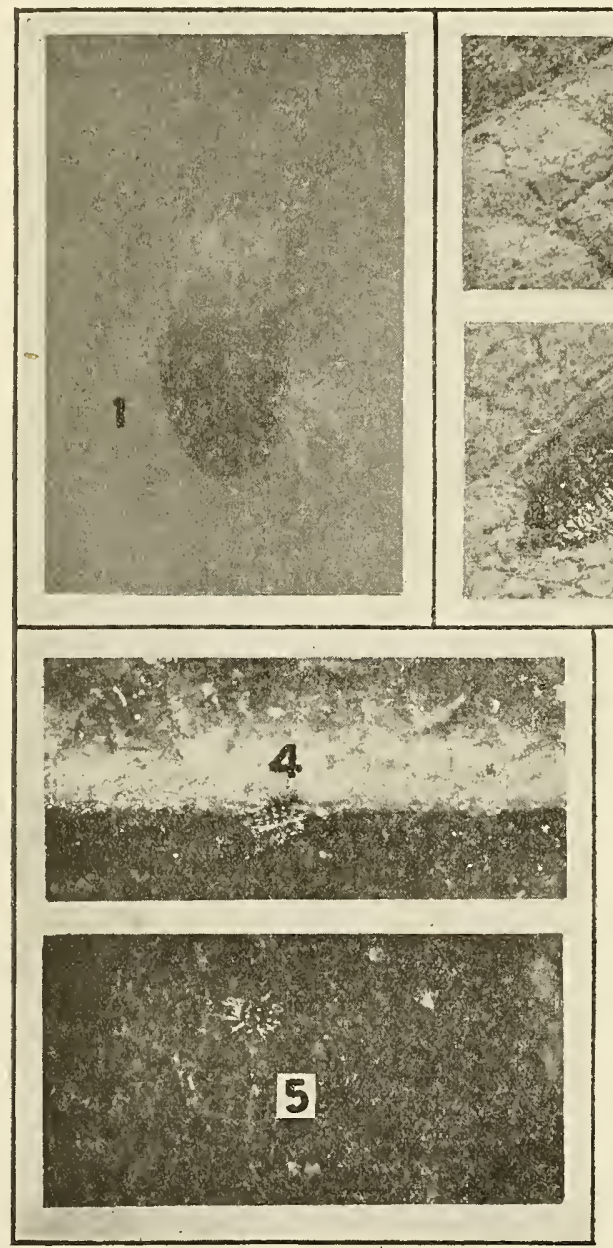

Figures 5 and 6 . Stages in development of the European red mite and the predator Ladybeetle.

Figure 5: 1. Quiescent nymph of European red mite, enlarged 80 times. 2. Larvae of predaceous enemy (Stethorus punctum Le Conte). 3. Pupa and adult of same, enlarged 10 times.

Figure 6: 4 and 5. Adult females of European red mite, enlarged 13 times. 
LIST of NATURAL ENEMIES of the EUROPEAN RED MITE

Acarina

*Anystis agilis Banks

* Seius pomi Parrott ${ }^{1}$

${ }^{*}$ Chelytus sp.

Neuroptera

*Chrysopa rufilabrus Burm.

* Conwentzia hageni Banks

Thysanoptera (thrips)

*Scolothrips sex maculatus Pergande

${ }^{*}$ Haplothrips sp.

Hemiptera-Miridae, Anthocoridae (bugs)

* Orius (Triphleps) insidiosus Say

${ }^{*}$ Hyaliodes vitripennis Say
Camptobrochis nebulosus Uhl.

Plagiognathus obscurus Uhl.

Campylomma verbasci Meyer

Diaphnidia capitata Van D.

Diaphnidia pellucida Uhl.

Coleoptera (beetles)

* Stethorus punctum LeConte

Stethorus picipes Casey

Diptera

*Syrphidae larvae

\section{USE OF SPRAYS}

\section{Historical}

Dormant sprays. The subject of what oils to use and at what strengths has received much attention from investigators. Newcomer (1933) recommends 4 percent oil for the Pacific Northwest, though later, in collaboration with other authorities, it was reduced to three (1938). Many workers recommend 3 percent oil in preference to other dilutions. British and continental workers are inclined to increase this to 4 or 5 percent, especially when combined with tar oils. Thus Kearns and Martin (1935) state that a 4 percent solution of lauryl rhodonate in 5 percent petroleum oil is effective. Experiments of Carroll and McMahon in Ireland result in their recommending 4 percent lubricating oil and 6 percent tar oil as a general winter or dormant spray. There are numerous references in the literature to the effect that tar oils are inefficient as ovicides, though occasional authors, such as Speyer (1934) in Germany, and Ward (1933) in Australia, recommend the use of tar distillates. It is not clear from the abstracts of these works whether lubricating oil is included or not, though it is evident from contemporary German publications that high boiling point fractions are preferred. In regard to reduction or increase of efficiency by addition of Bordeaux mixture or lime sulfur solution, Ginsburg (1936) states that Bordeaux mixture does not impair the ovicidal action against red mites when combined with oil and cresylic acid. Garman (1930) indicates a slight advantage where lime sulfur was combined with a stabilized oil. Gilliatt (1935), however, states that Bordeaux mixture promotes development of the European red mite presumably through destruction of natural enemies. (Also Kelsall, 1935.)

It is clear from all reports available that there is considerable variation in the action of oils on the red mite, but just what the variables are have not been demonstrated. Our own work as well as that of Worthley (1936) and Newcomer et al. (1938) indicates that spread and thoroughness of treatment are essential. The oil viscosity is a subject for dispute which is probably due to manufacturers' methods of altering viscosity in commercial products and the consequent difficulty of obtaining the same oil twice

*Known for Connecticut.

1 Probably several species. 
in succession. Some have specified "narrow cuts" in stating the preferred viscosity. Cresylic acid is believed by some to increase effectiveness, while thiocyanates would be expected to do the same thing. Stabilized oils have been condemned as less efficient but the evidence so far available does not warrant the assumption (Garman, 1930; Muggeridge, 1936). Paraffin base and asphalt base oils have received some consideration and it is apparent that both are effective. It is also evident that several factors, including volatility and cold test, have not been sufficiently explored to obtain their true meaning. As might be expected, these tests may have some value, for they indicate possible modifications of oil by dilution with viscosityreducing materials in order to meet specifications of the automobile trade.

Summer sprays. The use of lime sulfur was advocated in Connecticut (Garman, 1923) as a control of nymphs before adults appear on the leaves. It was also stated to be of some value as a summer spray applied about July 1, but danger of foliage burn was fully recognized. Both Sanders (1928) and Frost (1924) noted the adverse effects of dusting sulfur programs. Since then development of white oils by De Ong and others and the appearance of thiocyanates, derris and phenothiazine has altered the picture. It was demonstrated that proprietary mineral oils (Garman, 1923), used at 1 percent concentration, reduced red mites on foliage more than other sprays. White oil emulsions of much higher unsulfonatable residue have become more popular, however, because of greater safety, and many have succeeded in controlling the mite with them.

The need of including a fungicide has, however, hampered extensive practical application of the control, for Bordeaux mixture promotes mite development as already mentioned, and lime sulfur is incompatible with oils, causing foliage injury or fruit spotting. Bordeaux mixture is not used here largely because of fruit russetting, so that sulfurs, either lime sulfur or wettables, seem to be preferred. Many investigators have recognized the importance of allowing an interval before and after lime sulfur sprays to avoid damage, and Newcomer (1933) states that one to two months are necessary. For plums, Reed (1936) advocates the combination of Bordeaux mixture and oil, making the applications in June. Murphy (1936) tested the insecticidal activity of some of the aliphatic thiocyanates and reports an effective combination of lime sulfur and thiocyanate. Phenothiazine has been reported by Cutright (1937) to be ineffective. The use of derris for mite control has shown a tendency to increase, but our experiments in 1936 were not especially encouraging. Selenium has been tried as a control of citrus red spider and its use is mentioned by Gnadinger (1933) for the European red mite. Nicotine sulfate and pyrethrum sprays have given no satisfaction, according to the literature. Ammonium polysulfides have been used for red spiders out of doors by Compton (1938), and glues have been used successfully on certain species. Use of glue with lead arsenate is said by some to reduce the effectiveness of the combination for other insects, and the failure to control the eggs of mites is well known. Sulfonated oils of various kinds show promise in red spider control and their use as emulsifiers or spreaders has been tested by a number of workers.

One of the most complete sets of recommendations offered for mite control in orchards is that of Newcomer, Webster et al. (1938), which 
may be summarized as follows: (These recommendations apply to the Pacific Northwest area.)

1. Dormant oil (3 percent actual oil) dormant spray-not delayed dormant-or 3 percent dormant type miscible oil at delayed dormant period.

2. Summer oil about three weeks after calyx, using .75 percent oil (visc. 60 75 degrees S., unsulfonatable 85 percent or better). Two applications 8 to 10 days apart. The spray is combined with arsenate of lead for codling moth control.

\section{EXPERIMENTAL RESULTS AND FIELD OBSERVATIONS}

\section{Dormant Sprays}

Some of the data regarding oils for mite control are condensed in Tables 2 to 7 . Tables 2 to 6 inclusive give data on viscosity, stabilization, dilution with fuel oil, and addition of lime sulfur. Table 2 indicates that the cold test and volatility may be important factors. Tables 3 and 4 show that unstabilized emulsions have slightly superior killing action to stabilized oils but the difference is not great. Table 5 indicates that dilution with fuel oil is not desirable and Table 6 that there is only slight advantage from addition of lime sulfur.

Table 2. Performance of Several Oils Dissolved in Gasoline and Sprayed on European Red Mite Eggs ${ }^{1}$

\begin{tabular}{lcccc}
\hline \hline Oil & Volatility percent & Cold test & Viscosity & Percent hatch \\
\hline 6711 & 1.58 & $43^{\circ} \mathrm{F}$. & 652 & 9.2 \\
6710 & 1.69 & $14^{\circ} \mathrm{F}$. & 433 & 4.7 \\
6714 & 5.08 & $-27^{\circ} \mathrm{F}$. & 103 & 29.7 \\
6716 & 1.93 & $41^{\circ} \mathrm{F}$. & 704 & 6.0 \\
6718 & 3.57 & $19^{\circ} \mathrm{F}$. & 214 & 6.8 \\
6723,30 & $2.71-3.88$ & $-20-27^{\circ} \mathrm{F}$. & 168 & 28.1 \\
Check, gasoline only & $\ldots$ & $\ldots$ & 58.5 \\
\hline \hline
\end{tabular}

${ }^{1}$ One percent oil in gasoline sprayed on twigs with European red mite eggs.

Table 3. Comparison of Unstable Emulsion Forming a Film on Surface

Quickly, with Stabilized Emulsion in which Separation is Delayed

\begin{tabular}{ccrl}
\hline $\begin{array}{c}\text { Number } \\
\text { of } \\
\text { eggs used }\end{array}$ & $\begin{array}{c}\text { Number } \\
\text { of } \\
\text { tests }\end{array}$ & Percent hatched & \\
\hline 1423 & 9 & 1.6 & Unstable: Visc. 200, 2\% oil \\
1520 & 9 & 4.1 & Stabilized: Visc. 100, 2\% oil, April 4 \\
1125 & 7 & 8.5 & Stable: \\
1114 & 8 & 7.7 & Unstable: Visc. 100, 3\% oil, March 14 \\
464 & 5 & 59.0 & Check-no treatment \\
\hline
\end{tabular}

I Sprayed and hung outside exposed to the weather. 1.5 percent oil. Emulsified with sodium oleate plus casein, using the same formula for each. Higher viscosities gave no better results than the 195 sec. oil in this test. 
-Table 4. Comparison of Emulsion with Large Ori Globules with One Having Shaller Globules ${ }^{2}$

\begin{tabular}{rcrl}
\hline $\begin{array}{c}\text { Number } \\
\text { of } \\
\text { eggs used }\end{array}$ & $\begin{array}{c}\text { Number } \\
\text { of } \\
\text { tests }\end{array}$ & Percent hatched \\
\hline 990 & 6 & $\begin{array}{r}3.9 \\
1090\end{array}$ & $\begin{array}{l}\text { Unstable: Globules } 5-8 \mu, \text { few below } 5 \mu \text {, oil visc. } 100 \\
\text { Stabilized: Globules } 8 \mu-6.8 \mu \text {, none above } 6.8 \mu, \\
\text { mostly below } 5, \text { visc. } 100\end{array}$ \\
841 & 5 & 60.5 & Check-no treatment \\
\hline \hline
\end{tabular}

${ }^{2}$ Sprayed and hung outside exposed to the weather.

Table 5. Effect of Adping Fuel Oil on the Kiliting Power of a Lubricating Oil; Two Percent Emulsion

\begin{tabular}{|c|c|c|c|c|c|}
\hline $\begin{array}{l}\text { Analytical number } \\
\text { of oil used }\end{array}$ & $\begin{array}{l}\text { Percent } \\
\text { fuel oil }\end{array}$ & $\begin{array}{l}\text { Dates of treatment } \\
\text { and exam. }\end{array}$ & $\begin{array}{l}\text { Total } \\
\text { eggs }\end{array}$ & $\begin{array}{l}\text { Number } \\
\text { hatched }\end{array}$ & $\begin{array}{l}\text { Percent } \\
\text { hatched }\end{array}$ \\
\hline 6715 & 50 & $3 / 1-5 / 16$ & 123 & 30 & 24.6 \\
\hline 6715 & 33 & $3 / 1-5 / 16$ & 259 & 56 & 21.6 \\
\hline 6717 & 25 & $3 / 1-5 / 16$ & 507 & 59 & 11.8 \\
\hline Check & & $3 / 9-3 / 16$ & 77 & 43 & 55.5 \\
\hline
\end{tabular}

Table 6. Showing Effect on Red Mite Eggs of Adding Line Sulfur to Commercial Stabilized Eyulsions

\begin{tabular}{|c|c|c|c|c|c|}
\hline Oil & $\begin{array}{l}\text { Percent } \\
\text { oil content }\end{array}$ & $\begin{array}{l}\text { Lime sulfur } \\
\text { dilntion }\end{array}$ & $\begin{array}{c}\text { Number eggs } \\
\text { counted }\end{array}$ & $\begin{array}{c}\text { Number } \\
\text { tests }\end{array}$ & $\begin{array}{l}\text { Percent } \\
\text { hatched }\end{array}$ \\
\hline A. & 4 & None & 1504 & 10 & 4.2 \\
\hline A. & 4 & $1-50$ & 1554 & 10 & 3.0 \\
\hline B...... & 4 & None & 1979 & 10 & 3.8 \\
\hline B. & 4 & $1-50$ & 1265 & 10 & .56 \\
\hline
\end{tabular}

One of the problems facing orchardists is the combined control of aphids and red mites. Since tar oils do not kill red mites and lubricating oils in themselves are not especially effective against aphids, it appears important to have some spray which will combine the effectiveness of the two. Recently it has been shown that oils with di-nitro-cyclo-hexyl-phenol will do this. Oils of this kind containing 4 percent di-nitro-hexyl-phenol and diluted to 2 percent after tank mix emulsification were reasonably effective against both aphids and red mites in 1938 and against aphids alone in 1937. Tests during 1938 gave 80 to 85 percent reduction of red mites in one field test and approximately 95 percent kill in laboratory tests. In the field tests with the oil there was little or no action on mite-feeding thrips but considerably more on Seius species predators. 
Growers' controls have always been more successful when thoroughly applied and successful dormant sprays were noted in 1938. However, this year mite abundance was considered moderate, that is, not as severe as in 1936. On the other hand, during 1938 outbreaks occurred in orchards receiving no oil, much earlier than at other points where oil had been applied.

In Table 7 the effect of tar oils emulsified with turkey red oil compared with two commercial products seems to show some advantage for the home-made preparations. The actual grade of tar oil may have made some difference, however, but the tests indicate successful kills for one grade of tar oil at least. During 1936 a number of growers tried tar oils on a small scale and nearly all of them had outbreaks. Whether this was due to the method of application or destruction of natural enemies was not determined.

Table 7. Effect of Tar Otls and Tar Lubricating Onds on the Eggs of the European Red Mite, 1932 and 1935

\begin{tabular}{|c|c|c|c|c|c|}
\hline Oil & Concentration \% & Total eggs & No. hatched & $\%$ hatched & d Year \\
\hline 1. Tar oil........ & 6 & 233 & 5 & 2.1 & 1935 \\
\hline 2. Tar oil.... & 4 & 182 & 12 & 6.6 & 1935 \\
\hline 3. Tar oil.................. & $\frac{2}{1}$ & 264 & 15 & 5.6 & 1935 \\
\hline 4. Tar oil..................... & $\begin{array}{l}3 \\
2\end{array}$ & 240 & 4 & 1.6 & 1935 \\
\hline 5. Tar oil.................... & $\frac{2}{2}$ & 132 & 10 & 7.6 & 1935 \\
\hline 6. Tar oil . . . . . . . . . . . . . . & $\begin{array}{l}3 \\
1\end{array}$ & 391 & 13 & 3.3 & 1935 \\
\hline 7. Tar oil. ................ & 4 & 226 & 15 & 6.6 & 1935 \\
\hline 8. Commercial tar oil......... & $4 \%$ stock & 920 & 267 & 29.0 & 1932 \\
\hline 9. Commercial tar oil......... & $6 \%$ stock & 1,035 & 268 & 25.8 & 1932 \\
\hline 10. Commercial tar-lubr. oil.... & $6 \%$ stock & 201 & 5 & 2.4 & 1935 \\
\hline 11. Commercial tar-lubr. oil..... & $4 \%$ stock & 1,344 & 17 & 12.6 & 1932 \\
\hline 12. Check.... & None & 139 & 117 & 84.1 & 1935 \\
\hline 13. Check................ & None & 45 & 34 & 75.5 & 1935 \\
\hline 14. Check................ & None & 257 & 215 & 83.6 & 1935 \\
\hline 15. Check..... & None & 592 & 496 & 83.7 & 1932 \\
\hline
\end{tabular}

Numbers 1-7 emulsified with turkey red oil.

Twigs kept at $75-80$ degrees $F$. and about 60 percent relative humidity after spraying.

180 percent oil. 
Recommendations carried in our spray calendars for several years (see Conn. St. Coll. Ext. Service Bul. 248, 1938) call for 4 percent oil. This recommendation was made because growers failed to get satisfactory control during 1930 to 1937 and the greater strength was considered advisable. Successful commercial clean-ups were witnessed in 1938, however, with 3 percent strengths (4 percent of 83 percent concentrates) which may possibly be due to improvements in the manufacture of the emulsions. The specifications for oils used in tank mix preparations and a description of four successful commercial oils is given below. The method of preparing the tank-mix is also given.

Oil for Tank-Mix Preparations

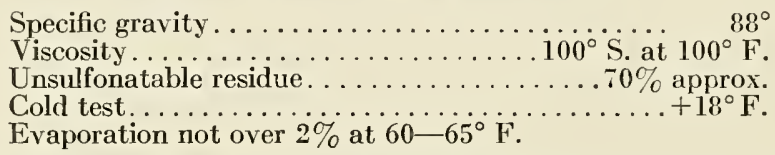

Place the oil in the tank. Add one pound of skim milk powder for every gallon of oil, running in a small amount of water-enough to allow pump to operate-and spraying back into the tank until a creamy emulsion is formed. Then fill the tank and start spraying the trees. Addition of a small amount of soap or other suitable spreader may help increase the spread on the trees.

\section{Description of Oils Used in Successful Commercial Preparations}

No. 1. 83 percent emulsion, mayonnaise type.

Viscosity of oil, $110-115^{\circ} \mathrm{S}$. at $100^{\circ} \mathrm{F}$.

Specific gravity .910 .

Emulsifier, ammonium caseinate plus sodium oleate.

Dilution used by grower, 4 percent.

No. 2. 83 percent emulsion, mayonnaise type.

Viscosity of oil, $150^{\circ} \mathrm{S}$. at $100^{\circ} \mathrm{F}$.

Specific gravity $25-30^{\circ} \mathrm{Be}$.

Dilution used by grower, 4 percent.

No. 3. Self-emulsifying oil, miscible oil type.

Viscosity of oil, 374 to 4.69 at $100^{\circ} \mathrm{F}$.

Specific gravity $24^{\circ} \mathrm{Be}$.

Dilution used by grower, 4 to 5 percent.

No. 4. Self-emulsifying oil, miscible oil type.

Viscosity of oil, $36^{\circ} \mathrm{S}$. at $100^{\circ} \mathrm{F}$.

Specific gravity $34^{\circ} \mathrm{Be}$.

Emulsifier, sulfonated vegetable oil.

Dilution used by grower, $62 / 3$ percent.

\section{Summer Sprays}

In consideration of any summer spray it is important to look for good egg mortality as well as mite kill because there are frequently more eggs on the leaves than any other stage. A spray giving the greatest kill of all stages is, of course, the most desirable. Likewise, a spray having the least effect on enemies or predators of the mite should be better than one seriously affecting natural control. Our information regarding the effect of sprays on the natural enemies is still imperfect, but there is enough information available to enable elimination of certain materials if enemies are to be preserved. The subject is discussed in more detail later. 
Lime sulfur spray was originally advocated to control the early stages of the mite shortly after hatching and before eggs of the first generation were deposited. Midsummer applications of lime sulfur have, in general, given poor results, although the earlier treatments seem to be of some benefit. The very general abandonment of strong lime sulfur in midsummer by the grower and a marked reduction in the amounts used in early season sprays has been apparent in the last three or four years. Likewise, the gradual elimination of the spray man on the ground has resulted in less thorough coverage of the undersides of the leaves. Some growers have attempted to overcome this deficiency by placing a spray platform close to the ground at the back of the tank, but it is evident that mechanical improvement of most spray outfits is in order so that all parts of the tree may be covered with the ease and rapidity of the "ride the tank method". It would also seem to be good practice to add a spreader, such as skim-milk powder or other compatible material, to the earlier sprays in order to increase the coverage of lime sulfur.

Wettable sulfurs and sulfur dusts have, for the most part, provided poor control of the European red mite because they do not affect the mites themselves unless the temperature is high, 80 to 90 degrees F. On the other hand, they may kill some of the predators. Preceded by successful dormant oil treatments, they were successful in the 1938 Graham experiments discussed later.

Nicotine sulfate does not kill egg, nymph or adult; but since it has little effect on the various enemies, it may be used without fear of destroying then where it is necessary to spray for aphids or leafhoppers, Table 14.

Derris or cubé sprays have given fair kills of the European red mite. These do not affect the eggs and within a week are probably lost as killing agents for young, recently hatched mites. Some growers have reported successful control with derris or cubé extracts combined with the regular sprays. Partial success was observed at Lebanon in 1936 (powdered root) and somewhat better results at Cheshire a year or two previous, on prunes. Rotenone extracts were not especially successful in our 1938 experiments when combined with the usual spray ingredients, Tables 10 and 11 . We have not tried these materials with summer oil but our 1938 experience indicates that thorough applications of the oil give good clean-ups without additional materials, Table 9.

Thiocyanates have considerable value as ovicides for red spiders and at least one of the commercial preparations kills their eggs at a dilution of 1 to 600 or 1 to 800 . Evidently this dilution is too great for eggs of the European red mite, for they failed to be of much benefit in the field and killed few in laboratory experiments. Stronger solutions are risky in view of the present information available and possible foliage injury.

Combined with summer oil at a dilution of 1 to 800 , no advantage whatever from addition of the thiocyanate could be seen in 1938, Table 9 .

Summer oils have given fair to good results in the hands of the grower as well as in experimental plots. A few growers have reported failures, and we have seen one failure where the material was applied very late in the season, near the first of September. The cause of these failures is still obscure, but we have attributed it mainly to cool weather during the time 
of the application. Applications during July and early August have as a rule worked much better, but the degree of control seems also to vary and much depends on the thoroughness of the treatment, the same as with dormant sprays. This is liable to be less complete for trees having abundant foliage as compared with light, or a large tree as compared with one of small size. Compared with the dormant oil, the summer oil is not regarded as quite so efficient. It is much easier to make complete coverage at the dormant period, and the dormant spray is also cheaper, if the amount necessary is taken into consideration.

Table 8. Mite Enemy Populations, 1936

\begin{tabular}{|c|c|c|c|c|c|}
\hline Location & Date & $\begin{array}{l}\text { Number } \\
\text { leaves }\end{array}$ & $\begin{array}{l}\text { Number } \\
\text { Seius }\end{array}$ & $\begin{array}{l}\text { Number per } \\
100 \text { leaves }\end{array}$ & $\begin{array}{c}\text { European red mite } \\
\text { infestation }\end{array}$ \\
\hline
\end{tabular}

New Haven Station Grounds

No sulfur spray

Mount Carmel

Station Orchard

"Young Orchard"

No sulfur spray

Mount Carmel

Station Orchard

"Old Orchard"

Check tree $^{1} \quad$ (I sulfur spray)

Mount Carmel

Station Orchard July 30

"Old Orchard"

August 8

July $\quad 27$

$27 \quad 15$

15

15

10

10

25

$\frac{25}{16}$

250 Present-no injury

160 Present-no injury

Sprayed with wettable sulfur

Hamden

Peck Orchard

Sprayed $6 \%$ oil,

July 31

no subsequent spray

Hamden

Townsend Orchard July $31 \quad 303 \quad 4 \quad 1.3 \quad$ Present-severe injury

Sulfur spray ${ }^{2}$

Hamden

Townsend Orchard July $\quad 31 \quad 295 \quad 147 \quad 49$ Present-no injury

Unsprayed

Lebanon

Graham Orchard July $\quad 15 \quad 184$

Sulfur spray

0

Lebanon

Trees nearby

Unsprayed

July $\quad 15$

50

54

108 Present-no injury

Branford

Plant Orchard

Sulfur spray ${ }^{3}$

I Check tree had one flotation sulfur-lead arsenate spray at the pink period.

2 A wettable sulfur containing some copper.

3 This orchard was one of the few escaping red mite injury, which had a full sulfur schedule. 
The number of summer applications needed to control an outbreak varies with the time of appearance. For example, outbreaks occurring in June may require two ${ }^{1}$ oil applications, whereas those occurring in August have not, in our experience, required more than one. The maximum oil recommended for summer sprays is 1.5 percent actual oil in the diluted spray and good results have been obtained with 1.25 percent. Sprays spaced one month apart have given satisfaction. The Washington recommendations (22) should be noted in this connection (see page 15). It is advisable, if oils are used, not to increase the deposit too much, since a heavy oil film interferes with the functions of the leaf for a time after application. Control should be secured with as few sprays as possible and hot weather is to be avoided. (Spray between 60 and 85 degrees F. Avoid temperature above 85 degrees, or below 60 degrees $\mathrm{F}$.).

Complications in the use of summer oils lic in the conflict between sulfur and oil, which may result in fruit and foliage spotting. This may be apparent, for example, if sulfur dust follows an oil treatment too closely or if the oil is used within a month of a lime sulfur spray. Again, if used too soon after lead arsenate or combined with it. it may set the arsenate so that there may be a residue problem at harvest. This condition will occur in Connecticut during July or early August but need not necessarily concern the orchardist in June except for early varieties. If used within two weeks of harvest, oils applied on such varieties as McIntosh and Cortland remove the bloom and result in dull and unattractive fruit. The bloom is likewise removed from prunes and plums if used too near the picking dates. Lighter, more volatile oils, are somewhat better in this respect and may be used perhaps a week later than the usual 80 to 100 viscosity white oil. The latest advisable date for use of oils on McIntosh and Cortland is the first week in August with a possible leeway extending to the fifteenth of that month.

Satisfactory commercial summer oil emulsions are on the market, most of them offered in the form of a thick mayonnaise emulsion. Tank mix oils are easily prepared by placing a good grade industrial white oil (80 viscosity and 90 to 100 percent unsulfonatable) in the tank, using 1.25 to 1.50 gallons and 1.25 to 1.50 pounds of skim-milk powder, adding a small amount of water and emulsifying the mixture by spraying back into the tank after the engine is started. When a creamy emulsion is formed, the tank is filled and the spraying of the trees begun. Outfits with good agitation are able to emulsify the mixtures satisfactorily without pumping back through the nozzles, but the engines should be started as soon as the materials are placed in the tank. Commercial emulsions, if broken, may be used by adding skim-milk powder to the emulsion, one pound of powder for each gallon of emulsion.

For promoting the development of mite and other enemies of the European red mite, the so-called lime-lead arsenate-fish oil spray has been used successfully in relatively dry seasons. This mixture consists of ten pounds of spray lime, three pounds of lead arsenate and one quart of fish oil. Linseed oil may be substituted for fish oil. The quality of fish oil recommended is light pressed menhaden ${ }^{2}$, but it is evident that lower

\footnotetext{
1 Possibly three under some conditions.

${ }^{2}$ Fatty acids not over 5 percent, stearines largely removed, flowable in fairly cool, 50-60 degrees F., weather.
} 
Table 9. European Red Mite Control, 1938

MacDonald Orchard, Wallingford. Wagener Variety, Sprayed July 6

\begin{tabular}{|c|c|c|c|c|c|c|c|}
\hline \multirow[b]{2}{*}{ Plots } & & \multicolumn{5}{|c|}{ Adults per 100 leaves } & \multirow[b]{2}{*}{ September 4} \\
\hline & & July 5 & July 13 & July 21 & July 26 & August 4 & \\
\hline & 1 & 45 & 0 & 0 & 0 & 0 & 20 \\
\hline & 2 & 33 & 12 & 8 & 5 & 0 & 0 \\
\hline A & 3 & 80 & 14 & 6 & 0 & 4 & 0 \\
\hline Oil & 4 & 125 & 14 & 0 & 0 & 0 & 0 \\
\hline & & 35 & 8 & .. & 0 & 0 & 0 \\
\hline Average & & 64 & 9 & 3 & 1 & .8 & 4 \\
\hline & 1 & 45 & 4 & 0 & 5 & 0 & 5 \\
\hline B & 2 & 36 & 2 & 0 & 0 & 0 & 0 \\
\hline Oil and & 3 & 166 & $4 \overline{6}$ & 8 & 10 & 0 & 0 \\
\hline lauryl & 4 & 86 & 0 & 2 & 10 & 0 & 0 \\
\hline thiocyanate & 5 & 40 & 18 & . & 0 & 4 & 0 \\
\hline Average & & 74 & 14 & 2 & 5 & .8 & 1 \\
\hline
\end{tabular}

Treatment:

Plot A Tank mix: Oil, 1.5 gallons; skim milk, 1.5 lbs.; water, 100 gallons.

Plot B Tank mix: Oil, 1.5 gallons; skim milk, $1.5 \mathrm{lbs}$; lauryl thiocyanate, 1 pint; water, 100 gallons.

Each plot division consisted of 9 trees. A commercial power outfit was used, spraying from the ground with a quad nozzle. Warm, clear day.

Average number of eggs per 100 leaves, June 22-28 in the treated plots, varied from 1,684 to 5,466. July 21 these trees averaged 272 per 100 leaves, a reduction of 84.0 to 92.4 percent.

Table 10. Results of Sprays on July 25 for Control of European Red Mites

\begin{tabular}{|c|c|c|c|c|c|c|}
\hline \multirow[t]{2}{*}{ Treatment } & \multirow[t]{2}{*}{$\begin{array}{l}\text { Dilution } \\
\text { in } \\
100 \text { gals. }\end{array}$} & \multirow[t]{2}{*}{ Tree } & \multirow{2}{*}{$\begin{array}{c}\text { Adult } \\
\text { females } \\
\text { per } 100 \\
\text { leaves } \\
\text { before } \\
\text { spray } \\
\text { July } 19\end{array}$} & \multicolumn{2}{|c|}{$\begin{array}{l}\text { Adult females } \\
\text { per } 100 \text { leaves } \\
\text { after spray }\end{array}$} & \multirow[t]{2}{*}{ Variety } \\
\hline & & & & July 28 & Aug. 3 & \\
\hline $\begin{array}{l}\text { Lauryl thiocyanate............. } \\
\text { Soap }(25 \%) \ldots \ldots \ldots \ldots\end{array}$ & $\begin{array}{l}1 \text { pint } \\
1 \text { quart }\end{array}$ & I 10 & 97 & 180 & 210 & Baldwin \\
\hline $\begin{array}{l}\text { Rotenone extract............. } \\
\text { Soap }(25 \%) . \ldots \ldots \ldots \ldots \ldots\end{array}$ & $\begin{array}{l}1 \text { pint } \\
1 \text { quart }\end{array}$ & $\begin{array}{l}\text { I } 18 \\
\text { G } 16\end{array}$ & $\begin{array}{l}143 \\
287\end{array}$ & $\begin{array}{l}180 \\
100\end{array}$ & $\begin{array}{l}230 \\
265\end{array}$ & $\begin{array}{l}\text { Baldwin } \\
\text { Baldwin }\end{array}$ \\
\hline 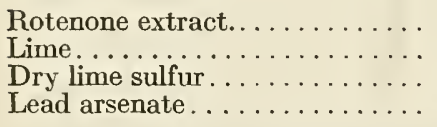 & $\begin{array}{l}1 \text { pint } \\
2 \text { lbs. } \\
4 \text { lbs. } \\
2 \text { lbs. }\end{array}$ & $\begin{array}{l}\mathrm{G} 12 \\
\mathrm{G} 14\end{array}$ & $\begin{array}{l}114 \\
186\end{array}$ & $\begin{array}{l}50 \\
30\end{array}$ & $\begin{array}{l}130 \\
140\end{array}$ & $\begin{array}{l}\text { Baldwin } \\
\text { Baldwin }\end{array}$ \\
\hline
\end{tabular}


Table 11. Results of Spray on July 30 for Control of European Red Mites

\begin{tabular}{|c|c|c|c|c|c|c|c|c|}
\hline \multirow[b]{2}{*}{ Treatment } & \multirow[b]{2}{*}{$\begin{array}{l}\text { Dilution } \\
\text { in } \\
100 \text { gals. }\end{array}$} & \multirow[b]{2}{*}{ Tree } & $\begin{array}{l}\text { Before spray } \\
\text { July } 28\end{array}$ & \multicolumn{4}{|c|}{$\begin{array}{cc}\text { After spray } \\
\text { August } 2 & \text { August } 12\end{array}$} & \multirow[b]{2}{*}{ Variety } \\
\hline & & & $\begin{array}{c}\text { Eggs Adults } \\
\text { per per } \\
100 \text { Ivs. } 100 \text { lvs. }\end{array}$ & $\begin{array}{c}\text { Eggs } \\
\text { per } \\
100 \text { Ivs. }\end{array}$ & $\begin{array}{l}\text { Adults } \\
\text { per } \\
100 \text { Ivs. }\end{array}$ & $\begin{array}{c}\text { Eggs } \\
\text { per } \\
100 \text { lvs. }\end{array}$ & $\begin{array}{l}\text { Adults } \\
\text { per } \\
100 \text { Ivs. }\end{array}$ & \\
\hline $\begin{array}{l}\text { Rotenone extract. } \\
\text { Dry lime sulfur. . } \\
\text { MnSO }_{4} . . . . . . . . \\
\text { Lead arsenate... . }\end{array}$ & $\begin{array}{l}1.5 \text { pints } \\
3 \mathrm{lbs} \text {. } \\
.25 \mathrm{lb} . \\
2 \mathrm{lbs} \text {. }\end{array}$ & $J 4$ & 3320 & 4390 & 190 & 2490 & 680 & Delicious \\
\hline
\end{tabular}

Note: Rotenone preparation reported in Tables 10 and 11 presumably contained 31 percent. acetone extract. Chemical tests later in the season indicated destruction of the rotenone in the original solution. Sprayed from the ground with power outfit using quad nozzle.

grades may also be used. The main difficulty with the lower grades lies in the fact that they may produce gummy mixtures which clog the strainer. It is not believed that this is a very serious obstacle, especially in warm weather when the oil flows more easily. Some of the lower grades, however, have a very offensive odor compared with the light pressed grade, and for those who object to the odor of fish oil, linseed oil may be used with equally good results. The spray should be applied in July without fish oil, and as with other sprays, very hot, damp weatler should be avoided. Field experiments in 1938 indicated that fish oil soap did not stick the mixture quite as well as fish oil, and previous experiments by Stoddard and Zappe indicated a slight advantage for oil as compared with the soap, "colloidal fish oil".

\section{Effect of Sprays on Predators or Natural Enemies}

During the winter the European red mite is in the egg stage on the smaller branches and twigs. Three of the more important enemies are also alive on the trees, on or under the bark of the trunk or larger branches, or on the twigs. It has been stated by various workers that oils kill some of these enemies, though they are fairly well protected by the bark and many escape. Elimination of mite predators following a lubricating oil spray has not been obtained in our field experiments although reduction has usually been noted, Table 12. Reduction has been greater where oils containing cresylic acid or di-nitro-cyclo-hexyl-phenol were employed, particularly as regards the Seius species. Tar oils seem to promote development of the European red mite, for we have seen the most serious outbreaks in orchards where they have been used and have observed fewer enemies of any sort after their use than with almost any other material. It is felt, however, that the action of any of the dormant oils is greatly intensified as far as the enemy populations is concerned by subsequent sprays of lime sulfur or other sulfur. Table 8.

Summer white oils have been shown to reduce ladybeetle populations, but do not seriously affect either thrips or mite predators, Table 14. More tests are needed, however, before positive conclusions can be drawn. 
Table 12. Observations on the Effects of Dormant Sprays on Red Mite Enemies. Examination During July

\begin{tabular}{|c|c|c|c|}
\hline Orchard and naterials used & $\begin{array}{l}\text { Number leaves } \\
\text { examined }\end{array}$ & $\begin{array}{l}\text { Number } \\
\text { Seius }\end{array}$ & $\begin{array}{l}\text { Number per } \\
100 \text { leaves }\end{array}$ \\
\hline \multicolumn{4}{|l|}{ Peck Orchard, } \\
\hline $6 \% \operatorname{tank} \operatorname{mix}$ oil $\ldots \ldots \ldots \ldots \ldots \ldots \ldots \ldots$ & 15 & 17 & 113 \\
\hline No subsequent sulfur spray . . . . . . . . . . & 15 & 10 & 66 \\
\hline $\begin{array}{l}\text { Station Farm, young orchard, } \\
\text { Kleenocil }^{1} \text { dormant, lime-lead arsenate....... }\end{array}$ & 15 & 23 & 152 \\
\hline \\
\hline $\begin{array}{l}\text { Lime sulfur-nicotine sulfate dormant, lime-lead } \\
\text { arsenate following. . . . . . . . . . . . . }\end{array}$ & 15 & 33 & 220 \\
\hline \multicolumn{4}{|l|}{ Station Farm, young orchard, } \\
\hline $\begin{array}{l}\text { Ready-mix oil }{ }^{2} \text { emulsion dormant, lime-lead ar- } \\
\text { senate following. . . . . . } \ldots \ldots \ldots \ldots \ldots \ldots\end{array}$ & 15 & 45 & 300 \\
\hline Station Farm, young orchard, & & & \\
\hline Tar oil dormant, lime-lead arsenate following. . & 15 & 23 & 152 \\
\hline 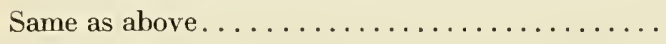 & 15 & 20 & 132 \\
\hline 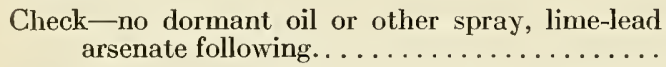 & 15 & 56 & 372 \\
\hline
\end{tabular}

1 Dormant oil containing cresylic acid (Commercial).

2 Dormant oil without cresylic acid (Commercial).

Table 13. Effect of Sprays on Mrte Enemies. Westwoods, 1936

\begin{tabular}{|c|c|c|}
\hline Treatment & $\begin{array}{c}\text { Number Seius } \\
\text { per } 100 \text { leaves } \\
\text { before }\end{array}$ & $\begin{array}{l}\text { Number Seius } \\
\text { per } 100 \text { leaves } \\
\text { after }\end{array}$ \\
\hline 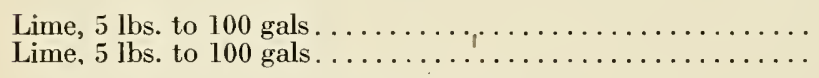 & $\begin{array}{l}320 \\
214\end{array}$ & $\begin{array}{l}168 \\
160\end{array}$ \\
\hline $\begin{array}{l}\text { Tank mix white oil emulsion, } 1 \% \text { oil. } \ldots \ldots \ldots \ldots \ldots \ldots \ldots \ldots \\
\text { Tank mix white oil emulsion, } 1 \% \text { oil. } \ldots \ldots \ldots \ldots \ldots \ldots \ldots\end{array}$ & $\begin{array}{l}256 \\
144\end{array}$ & $\begin{array}{l}196 \\
136\end{array}$ \\
\hline Lead arsenate, 3 lbs. to 100 gals. . . . . . . . . . . . & 102 & 28 \\
\hline 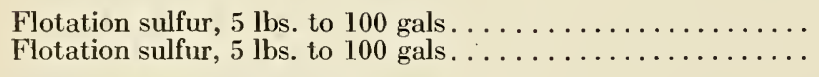 & $\begin{array}{l}73 \\
33\end{array}$ & $\begin{array}{l}4 \\
0\end{array}$ \\
\hline 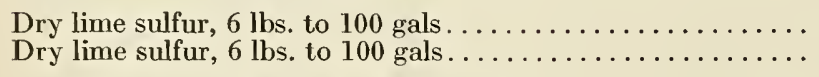 & $\begin{array}{r}111 \\
32\end{array}$ & $\begin{array}{l}0 \\
0\end{array}$ \\
\hline 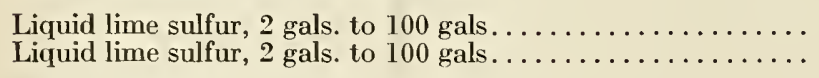 & $\begin{array}{l}46 \\
78\end{array}$ & $\begin{array}{l}0 \\
0\end{array}$ \\
\hline Check-no spray........ & 94 & 150 \\
\hline
\end{tabular}


Table 14. Comparative Kill of European Red Mite and Some of Its Enemies by Three Different Sprays ${ }^{1}$

\begin{tabular}{|c|c|c|c|c|}
\hline - & Sprays & $\begin{array}{l}\text { Kill of } \\
\text { European } \\
\text { red mites } \\
\%\end{array}$ & $\begin{array}{c}\text { Kill of } \\
\text { mite-feeding } \\
\text { thrips } \\
\%\end{array}$ & $\begin{array}{c}\text { Kill } \\
\text { of } \\
\text { ladybeetles } \\
\%\end{array}$ \\
\hline
\end{tabular}

$1 \%$ summer oil. ................ $87-89 \quad 33$

$4 \%$ derris, 1 lbs. to 100 gallons. . . . . . . . . .

1 Estimated from counts of foliage before and after spraying.

Lime sulfur in itself has been thought to be harmless to enemies of the red mite, but there is evidence, Table 13, that this material as well as wettable sulfur destroys at least one of the more important of them. A single application at the pink stage has not affected Seius sp. in our experiments and these enemies have built up successfully in our Wallingford experiments after a pink lime sulfur and calyx wettable sulfur spray, Table 17. A pink spray of flotation sulfur did not affect these enemies in our 1936 experiments. Outbreaks have been observed to follow sulfur dust programs, in spite of the fact that good kills of the mites themselves have sometimes been obtained in hot weather. This is thought to be due to kill of Seius sp.

Nicotine and pyrethrum apparently have little effect on the enemies of the European red mite. Strong pyrethrum sprays, however, will probably kill the ladybeetle predator.

Derris and cubé sprays eliminate many of the natural enemies. The effect of rotenone extracts alone on Seius is not as great as might be expected, for many have been seen alive after an application.

Lime appears to be ineffective against the natural enemies.

Lead arsenate is only slightly deleterious.

Not much is known concerning the effect of thiocyanates.

Little is known concerning the action of glues on mite predators.

Bordeaux mixture, while not used on apples in Connecticut to any extent, has been reported to promote outbreaks of the European red mite and presumably destroys the natural enemies.

So far as known at the present time, about the only materials that can be used without serious effect on the natural enemies are summer and winter lubricating oils without cresylic or similar toxicants, lead arsenate and lime. Nicotine sulfate and possibly pyrethrum fall into the latter class, but little is known of the effect of thiocyanates. 
Table 15. Effect of Spray Programs on Eggs on the Trees at the End of the Season

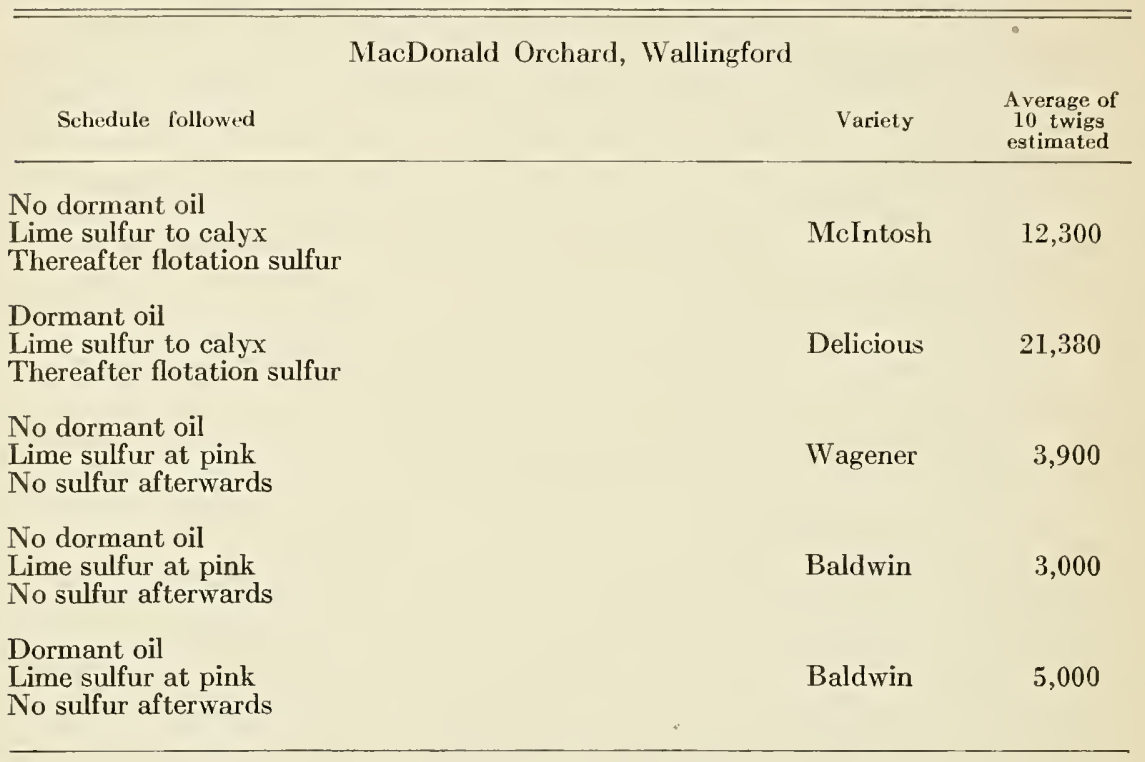

Graham Orchard, Lebanon

Count of eggs on 15-inch twigs, 100 twigs per plot

Random sample, 10 twigs each from 10 trees

Schedule followed

Variety

Average

per twig

No dormant oil

Lime-lead arsenate-fish oil

Baldwin $\quad 16.5 \pm 1.8$

Throughout season

Dormant oil

Lime sulfur to calyx

Thereafter lime-lead arsenate fish oil

Baldwin $\quad 600 \pm 104$

Dormant oil

Lime sulfur to calyx

Thereafter flotation sulfur

Baldwin $\quad 140 \pm 36.8$

No dormant oil

Lime sulfur to calyx

Flotation sulfur rest of season

Baldwin $\quad 294 \pm 80$

During the very general outbreak of 1936 , it was observed that trees receiving no spray were green without exception. Likewise, plots sprayed at the Experiment Station farm at Mount Carmel with materials containing no sulfur remained green. Plots a short distance away, receiving dormant oils and sulfur sprays during the summer, had an outbreak of mites. Check trees in the latter plot receiving only a pink spray of flotation sulfur remained free. A portion of the first mentioned orchard was then 
sprayed with dormant oil and sulfur with the result that mites became abundant there during August, 1938, although they did not appear in the remaining portion receiving no sulfur. During these years, orchards where no sulfur had been used had much lower twig infestations of eggs during the winter than similar plots alongside receiving sulfur. Results from the Graham Orchard, Table 15, support this idea.

\section{Discussion of Problems Connected with Summer Control}

Although we cannot recommend to Connecticut growers without any limiting qualifications a straight schedule of lime, lead arsenate and fish oil, it is evident from our experiments since 1931 at Mount Carmel, and from many observations in commercial orchards where it has been tried, that the schedule is successful in preventing outbreaks of the European red mite. The MacDonald experiments indicate that enemy populations may build up after two early sulfur applications. The main complication lies in disease control during wet seasons, and there seems to be little doubt that the grower will have to abandon it when threatened by scab or other disease. Fruit spot and black rot, both on fruit and foliage, have to be contended with in addition to scab, and the schedule is certainly not suited to orchards where scabbing varieties, such as McIntosh, are interplanted with others.

The problems connected with oil applications during the summer have been discussed. Interference with sulfur programs, removal of fruit bloom if used too late, and spray residue in dry seasons are the more outstanding. Frequently these risks are too great to be taken, though oils can and have been used successfully to reduce infestations. If there is a question between control of apple maggot and red mites, the maggots must receive first consideration.

Lime sulfur, as observed especially in midseason sprays, has a tendency to promote outbreaks. Observations in 1938 furthermore indicate that their effects last over one year, for an outbreak occurred in one of our orchards where no spray had been applied since the previous summer. Other trees in this orchard were free from mite attacks even though they received sulfur in 1938. Lime sulfur in midsummer is often accompanied by foliage burn, a factor against its use at that time unless measures to prevent burn are employed.

Glues such as bill poster glue and casein waterproof glue have been used in orchard work, but their value as European red mite controls is uncertain.

\section{Occurrence and Control on Peaches and Plums}

The European red mite occasionally becomes abundant on peaches, usually - but not always - on trees interplanted with infested apples. In general, no control is advisable on peaches, but it is sometimes necessary. Control on the interplanted apples is important and the peaches can be sprayed with stabilized oil to which lime sulfur is added for leaf curl. Use lime sulfur at 3 gallons per 100 and the oil at the usual strength.

It is not generally necessary to spray plums for red mite control in Connecticut, but if necessary a 3 percent oil may be used. Summer oil combined with Bordeaux mixture is recommended by Reed (23) for applications during June. 


\section{Tests of Different Control Schedules}

The following account of experiments with mite-reducing schedules is given so that a more complete picture of the work may be obtained. A few pertinent observations in orchards where similar attempts have been made by various orchardists is also included.

\section{The Mount Carmel Experiments}

A series of experiments was begun in 1930 by M. P. Zappe and E. M. Stoddard, using no sulfur sprays on McIntosh and other varieties. Except for McIntosh and Fall Pippin, the amount of good fruit obtained was larger for the so-called "lime-lead arsenate-fish oil" treatment than with any other. This treatment was continued each succeeding year until 1938, and scores obtained continued to indicate a high efficiency for the limelead arsenate-no-sulfur schedule. It was during this period that absence of European red mites was noted. As reported by them, the amount of good fruit free from insect and disease blemishes was as follows on varieties not subject to $\mathrm{scab}^{1}$ :

$\begin{array}{ccc}\text { Year } & \text { Good } \% & \text { Scab \%1 } \\ 1930 & 76 & 1.2 \\ 1933 & 95 & .69 \\ 1934 & 65 & .6-1 \\ 1935 & 85-87 & 1 \\ 1936 & 95 & 1-2 \\ 1937 & 78-87 & 1-8\end{array}$

The amount of disease, including fruit speck and sooty blotch as well as scab, appeared to be a negligible factor when the spray was applied to varieties other than McIntosh and Fall Pippin.

In these tests, sulfur was omitted entirely and results thus appeared satisfactory for a period of seven years. However, comparison of foliage in sulfured and unsulfured plots in this orchard during 1938 indicated a decided advantage for sulfur schedules.

\section{The MacDonald Orchard Experiments}

Spraying experiments were begun in 1937 at the MacDonald farm in Wallingford, the owner applying the sprays. In all, there are 11 plots consisting of McIntosh, Delicious, Baldwin, Greening, Wagener, Wealthy, Duchess, and other odd varieties. During preceding years the owner had experienced extensive spray burn of the foliage as well as red mite injury. He had been troubled both by aphids and leafhoppers, which complicated the matter.

The McIntosh, Delicious and other varieties were given a dormant oil followed by a rigorous schedule of lime sulfur plus catalytic safeners ${ }^{2}$. All sulfur was omitted from Baldwins and Greenings the first year, but the fruit obtained was not entirely satisfactory from a commercial standpoint and attempts were made to improve the schedules in 1938 . There were two plots of Baldwins, one of which received a dormant oil during 1937 and 1938, and the other did not. The Wageners received no oil in 1937 but the plot was divided in 1938 and half given an application of di-nitro-hexyl-

1 Excludes McIntosh and Fall Pippin; includes Baldwin, Greening, Russet, Northern Spy, Sutton, and King.

2 Active ingredient, Manganese sulfate. 
phenol in oil. During 1937, there was no difference as far as mites were concerned in the Baldwin plots receiving no sulfur or a minimum of sulfur, whether or not oil had been applied. During 1938, the oil-treated plot was of a better color and had fewer mites. Plot No. 1, receiving no oil but with sulfur sprays up to and including calyx, became infested from nearby trees, but predators cleaned it up before the trees became uniformly brown. During 1938, however, in both Baldwins and other plots receiving no sulfur, there developed an infection of fruit spot or speck (Phoma pomi), but this also appeared on Wealthys and McIntosh receiving a greater number of sulfur sprays. Evidently 1938 was very favorable to diseases of this kind. European red mites became abundant in the half of the Wagener plot receiving no oil and in several other places where heavy sulfur schedules were followed.

Results in the MacDonald orchard confirmed those in the Graham orchard, namely, that the use of a dormant oil is beneficial in seasons such as 1938. They also confirm our Mount Carmel experiments to the effect that red mite enemies can be increased to an effective point by the omission of sulfur during midsummer. The results on Baldwins, however, were discouraging because of development of fruit spot (Phoma pomi), which might have been prevented in part by heavier sulfur schedules. It is apparent from the work here that no flat recommendations can be made for general omission of sulfur from the schedule.

The Townsend Orchard Experiments

This orchard consists of Baldwin, McIntosh, Rome Beauty, Cortland, Delicious, and others. The Baldwins were divided into two plots in 1937, one receiving no sulfur and the other treated with sulfur sprays. No oil was used on these trees. Mites previously scarce in the sulfured half became abundant enough to bronze both Baldwins and Delicious during the second year. No fruit speck developed in the unsulfured portion of this orchard, and leaf spot and black rot were not serious. Fruit spot was abundant on unsprayed trees about 100 feet distant. During 1937, however, leaf spot appeared to be very serious in the portion receiving no sulfur.

Results in the Townsend orchard confirm those at Mount Carmel, namely, that mites do not develop in trees having no-sulfur schedules. They indicate, however, that caution is necessary in regard to indiscriminate omission of sulfur because of leaf spot and black rot. Fruit spot did not develop here in 1938, but, as indicated above, it was serious on unsprayed Baldwins, indicating that the schedule was successful in control of that disease.

\section{The Graham Orchard Experiments}

Experiments were begun during 1936 in a mixed block of Baldwins and McIntosh. Here scab was serious not only on the McIntosh but also on the Baldwins. A number of treatments were investigated in 1936, and the best of those tried consisted of a dormant oil with lime sulfur up to the calyx period and then flotation sulfur. The oil used was a commercial emulsion with a medium oil emulsified with a special emulsifier and marketed in the form of a stiff mayonnaise dressing. In the plot under consideration, mites did not become abundant enough to do much harm until August 5, and the trees remained green until the infestation subsided shortly after the middle of the month. (See Fig. 3, Russet plot.) 
During 1937 the plots were arranged differently and a no-sulfur treatment was included. Mite infestations were lacking in all plots because of the heavy rainfall during July and August. However, twig counts during the fall indicated a decided advantage for no-sulfur sprays, and the fruit in general from Baldwins in that plot was not significantly worse than from the rest of the orchard.

In 1938, the same plan of treatment was followed. This year heavy rains and long, hot, damp periods in July caused considerable difficulty in the no-sulfur plots, both in amounts of scab developing and leaf burn and black rot. The best schedule consisted of dormant oil followed by lead arsenate plus flotation sulfur throughout the season. This plot was alongside one receiving no dormant oil, and lead arsenate and flotation sulfur throughout. Mites became abundant here during July. Inspection about the first of September showed a very marked difference in the plots. A definite line developed between them, with trees on one side, brown, and on the other, green. (See Table 16.)

\begin{tabular}{clll} 
Plot & \multicolumn{1}{c}{ Treatment } & Mites & Foliage \\
A. & No oil, no sulfur & Few & Green \\
B. & $\begin{array}{l}\text { Dormant oil } \\
\text { Lime sulfur to calyx } \\
\text { No sulfur after calyx }\end{array}$ & Few & \\
C. & $\begin{array}{l}\text { Dormant oil } \\
\text { Flotation sulfur following }\end{array}$ & Few & Green \\
D. $\quad \begin{array}{l}\text { No dormant oil } \\
\text { Flotation sulfur } \\
\text { Lime sulfur at midseason }\end{array}$ & Many & Brown
\end{tabular}

As will be seen, results in this orchard confirmed, in general, those of 1936 in the same orchard: that a dormant oil is needed and that the infestation may be held to reasonable figures by this treatment alone during years similar to 1936 and 1938. It also confirms our results at the Experiment Station farm: that the red mite is not serious where sulfur is omitted, but that the full "no sulfur" schedule is not suitable for mixed varieties such as Baldwin and McIntosh.

\section{Observations in Commercial Orchards}

Observations in commercial orchards during 1937 and 1938, although not made with the detail of the foregoing experiments, have yielded some valuable information. The Curtis orchard in Bantam experienced an outbreak in 1937 which covered a fairly large area in one block. During 1938 few winter eggs could be found in the heavily infested portion, but they were very numerous outside the area bronzed in 1937. A portion of the bronzed area was left without special mite treatment during 1938 but there was no development of the European red mite there. Stethorus ladybeetles were seen to be abundant and several inspections during the summer indicated that they had been able to clean up what mites were left from the previous season. In another portion heavily infested with eggs, most of the block was oiled but two rows were left through the center. After the eggs began to hatch in the spring in the unoiled rows, ladybeetle eggs were seen to be abundant and they were able to keep down the infestation. Evidently they had congregated on these two rows after their food had been largely destroyed in the remaining portion of the orchard. Seius mites and other enemies in general were scarce on the trees throughout 
Table 16. Comparison of Several Different Schedules for Control of the European Red Mite on Baldwins

Graham Orchard, Lebanon, 1938

\begin{tabular}{|c|c|c|c|c|c|c|}
\hline $\begin{array}{c}\begin{array}{c}\text { Block } \\
\text { and } \\
\text { Treatment }\end{array} \\
\end{array}$ & Dates & $\begin{array}{l}\text { Adults } \\
\text { per } \\
100 \mathrm{lvs} .\end{array}$ & $\begin{array}{l}\text { Nymphs } \\
\text { per } \\
100 \text { lvs. }\end{array}$ & $\begin{array}{c}\text { Eggs } \\
\text { per } \\
1001 \mathrm{lss} .\end{array}$ & $\begin{array}{l}\text { Disease } \\
\text { control }\end{array}$ & $\begin{array}{c}\text { Foliage } \\
\text { condition }\end{array}$ \\
\hline $\begin{array}{l}\text { A } \\
\text { Lime-lead arsenate-fish } \\
\text { oil. } \\
\text { No dormant spray. }\end{array}$ & $\begin{array}{l}\text { May 9 } \\
\text { May } 23 \\
\text { June } 8 \\
\text { June 22 } \\
\text { July 10 } \\
\text { July 28 } \\
\text { August } 8 \\
\text { August } 31\end{array}$ & $\begin{array}{l}60 \\
7 \\
0 \\
1.5\end{array}$ & 23.6 & $\begin{array}{l}74.8 \\
61 \\
129\end{array}$ & Poor & Poor \\
\hline $\begin{array}{l}\text { B } \\
\text { Dormant oil } \\
\text { Lime sulfur to calyx, } \\
\text { lime-lead arsenate- } \\
\text { fish oil thereafter. }\end{array}$ & $\begin{array}{l}\text { May 9 } \\
\text { May } 23 \\
\text { June } 8 \\
\text { June } 22 \\
\text { July } 10 \\
\text { July 28 } \\
\text { August } 8 \\
\text { August } 31\end{array}$ & $\begin{array}{r}23 \\
8 \\
0 \\
27\end{array}$ & 1.8 & $\begin{array}{l}3.4 \\
0 \\
4\end{array}$ & Fair & Poor \\
\hline $\begin{array}{l}\text { C } \\
\text { Dormant oil. } \\
\text { Flotation sulfur-lead ar- } \\
\text { senate rest of season. }\end{array}$ & $\begin{array}{l}\text { May 9 } \\
\text { May } 23 \\
\text { June } 8 \\
\text { June 22 } \\
\text { July 10 } \\
\text { July 28 } \\
\text { August } 8 \\
\text { August 31 }\end{array}$ & $\begin{array}{r}6 \\
3 \\
3 \\
85\end{array}$ & 0 & $\begin{array}{l}0 \\
0 \\
0\end{array}$ & Good & Good \\
\hline $\begin{array}{l}\text { D } \\
\text { No dormant oil. } \\
\text { Flotation sulfur } \\
\text { rest of season }\end{array}$ & $\begin{array}{l}\text { May } 9 \\
\text { May } 23 \\
\text { June } 8 \\
\text { June } 22 \\
\text { July } 10 \\
\text { July 28 } \\
\text { August } 8 \\
\text { August } 31\end{array}$ & $\begin{array}{r}184 \\
102 \\
45 \\
261\end{array}$ & 31.9 & $\begin{array}{r}49 \\
126 \\
1678\end{array}$ & Good & Brown \\
\hline
\end{tabular}

Table 17. European Red Mite Control

Comparison of Plots at MacDonald Orchard, 1938

\begin{tabular}{llc}
\hline \hline $\begin{array}{c}\text { Block } \\
\text { and } \\
\text { treatment }\end{array}$ & Date & $\begin{array}{c}\text { Adult females } \\
\text { per 100 leaves }\end{array}$ \\
\hline Block 1 & May 10 & 40.5 \\
No oil. & June 10 & 67.0 \\
Sulfur to calyx & July 16 & 266.0 \\
Lime-lead arsenate-fish oil & August 4 & 47.0 \\
thereafter. & August 16 & 0 \\
(Baldwin) & September 4 & 0 \\
\hline Block 2 & May 10 & 81.0 \\
Dormant oil. & June 10 & 60.0 \\
Sulfur to calyx. & July 16 & 121.0 \\
Lime-lead arsenate-fish oil & August 4 & 59.0 \\
thereafter. & August 16 & 3.0 \\
(Baldwin) & September 4 & 1.0 \\
\hline \hline
\end{tabular}


the orchard, indicating that the ladybeetles had been largely responsible for reduction of red mite numbers.

Observations during 1938 in four commercial orchards using the limelead arsenate-fish oil schedule showed three of the four badly spotted with Brooks fruit spot, though in none of them was there any mite outbreak. In some of these orchards there was more or less trouble from the same disease in plots receiving sulfur, but it seemed to be worse in unsulfured or reduced sulfur areas. Thus, of the six commercial orchards examined in 1938 , including two used for experiments, only two succeeded in controlling the Brooks spot, and four failed. In all cases where failure was noted, only partial control was obtained with the use of more complete sulfur schedules.

Several red mite outbreaks were investigated in 1938, the worst trouble appearing during the latter part of June and the first of July. In all cases investigated the infestation had started in varieties such as McIntosh where dormant oils were omitted and heavy lime sulfur schedules employed. These observations in general support the idea that sulfur schedules may promote rather than check outbreaks.

\section{SUGGESTIONS TO GROWERS}

As a result of the foregoing experiments and observations, the following suggestions are offered:

(1) Examine the trees carefully during the winter when pruning. If no red mite or aphid eggs are found, omit the dormant spray. If only an occasional red mite egg is found and no clusters, it may pay to take a chance and omit the oil ${ }^{1}$. If clusters of eggs are found frequently on the twigs, or heavily infested centers show up on twigs and branches (Fig. 1), it is advisable to treat thoroughly with oil.

(2) Make a dormant or delayed dormant application of oil, using 3, better 4 percent actual oil in the mixture. Cover all parts of the tree as thoroughly as possible. Make a point to spray the tree from opposite sides, or spray across the rows if necessary to complete the job. If aphids are present, oils containing di-nitro-hexyl-phenol may be used or nicotine sulfate may be added to delayed dormant sprays. Oils of at least 100 degrees S. viscosity should be used, but if lighter oils are employed, the dosage, !n general, should be increased. Types of successful commercial oils are given on page 18. Emulsions of good wetting properties are preferred and if the wetting is not satisfactory, agents such as soap or other material may be added to provide thorough coverage. Dates for these applications usually fall between March 1 and April 15. Select a fairly warm, clear period and a quiet day if possible.

(3) Use 1.25 percent white lubricating oil emulsion during the last week of June or the first week of July, combining lead arsenate for maggot control but omitting all sulfur. This applies only to varieties ripening on or after the middle of September, since it is believed that two and onehalf months should be allowed between spray and harvest for such com-

\footnotetext{
1 Judgment among growers regarding this point will vary so an arbitrary limit may be suggested such as one red egg for every five twigs, approximately 10 to 15 inches long. Infestations have developed from as few as three to six eggs per 15-inch twig, but the exact lower limit for a dangerous infestation has not been determined.
} 
binations in order for the spray to be washed off by rains. If the season is rainy and wet at the time suggested, disregard mite control and proceed with measures to stop diseases. Lime sulfur sprays at the pink and calyx periods are of some value in reducing the number of mites but should not be depended upon entirely. A spreader is believed to be useful for mite control, and it is important to cover the undersides of the leaves where most of the mites are to be found at that time. Apply summer oils not less than one month before or after lime sulfur or two weeks before or after a wettable sulfur spray.

(4) Red mites prefer clear weather and develop most rapidly under such conditions. Long continued rainy and cloudy spells are detrimental and no controls are usually needed. On brown trees, the infestation may be subsiding and therefore treatment is unnecessary. On trees just beginning to show brown, where vast numbers of mites are present, treatment is advisable. Periods for successful summer treatments range between June 20 and about August 10. Two, possibly three, treatments may be needed in severe infestations. Controls during July and August are often obtained with one. Infestations during late July and early August frequently cure themselves if weather conditions are unfavorable, and late August infestations can be safely ignored for the season. Too much faith in the weather, however, is inadvisable.

(5) If the season has been wet and the disease situation is becoming serious, disregard the mites completely. By no means should July applications of lead arsenate be omitted because of the danger of apple maggot and late feeders such as the red banded leaf roller, known locally as the "green fruit worm" or "side worm".

(6) Use reduced sulfur schedules only when and where it is known they can be handled successfully (after trial on a small scale for a number of years) without endangering disease control. These schedules are not suitable for McIntosh, Fall Pippin, and Cortland. 


\section{PARTIAL BIBLIOGRAPHY}

1. Carroll, J. and McMahon, E. Jour. Dept. Agr. (Irish Free State), 33, no. 1: pp. 48-52. 1935. Same, 31: pp. 190-198. 1932.

2. Cutright, C. R. Effect of codling moth schedules on other orchard insects. Jour. Econ. Ent., 30: pp. 413-417. 1937.

3. Compton, C. C. Note in Proc. Seventh Annual Meeting of the North Central States Entomologists, p. 96. 1938.

4. Cottier, W. The European red mite in New Zealand. New Zeal. Jour. of Sci. and Technol., XVI: pp. 39-56. 1934.

5. Cottier, W. The natural enemies of the European red mite in New Zealand. New Zeal. Jour. of Sci. and Technol., XVI: 68-80. 1934.

6. Frost, S. W. Four year experiments on the control of the red spider. Jour. Econ. Ent., 17: p. 103.1924.

7. Garman, Philip. The European red mite. Conn. Agr. Exp. Sta., Bul. 252. 1923.

8. A study of various oils and emulsions for killing the eggs of the European red mite. Conn. Agr. Exp. Sta., Bul. 315: pp. 571-575. 1930.

9. Observations on the European red mite and its control. Conn. Agr. Exp. Sta., Bul. 396. 1937.

10. European red mite control investigations. Conn. Agr. Exp. Sta., Bul. 408: pp. 219-220. 1938.

11. Gilliatt, F. C. Some predators of the European red mite (P. pilosus C. \& F.) in Nova Scotia. Canad. Jour. Research, D13: pp. 19-38. 1935.

12. - The European red mite (Paratetranychus pilosus C. \& F.) in Nova Scotia. Canad. Jour. Research, D13: pp. 1-17. 1935.

13. Ginsburg, J. M. Results of home-made oil emulsions for orchard spraying. Jour. Econ. Ent. 29: pp. 361-364. 1936.

14. Gnadinger, C. B. Selenium. Insecticide material for controlling red spider. Ind. Engin. Chem., XXV: pp. 633-637. 1933.

15. Kearns, H. G. H. and Martin, H. Investigations of egg killing washes. Ovicidal properties of lauryl rhodonate. Rept. Agr. Hort. Res. Sta., Bristol (England), pp. 49-57. 1935.

16. Kelsall, A. Iron sulfate and lime sulfur mixture. Rept. Ent. Soc. Ontario, 65: pp. 73-76. 1935.

17. Listo, J. Hedelemapuupunkin torjunta (The control of the fruit tree red mite), (Finland) Valt. Maatalousk. Tiedon. No. 93. 1935. See Rev. Appl. Ent., 23: 350. 1935.

18. Muggeridge, J. Ent. Section Rep. Dept. Agr., New Zealand, 1933-34: pp. 4243. 1934. See Rev. Appi. Ent., 22: p. 724. 1934.

19. Muggeridge, J. Ent. Section Rep. Dept. Agr., New Zealand, 1935-36: pp. 4950. 1936. See Rev. Appl Ent., 25: p. 80. 1937.

20. Newcomer, E. J. and Yothers, M. A. Biology of the European red mite in the Pacific Northwest. U. S. Dept. Agr. Tech. Bul. 89. 1929.

21. Newcomer, E. J. U. S. Dept. Agr. Circ. 270: pp. 16-19. 1933.

22. Newcomer, E. J. and Webster, R. L. et al. Recommendations for codling moth and orchard mite control in the Pacific Northwest. Washington State College Extension Service, Ext. Bul. 240: p. 11. 1938.

23. Reed, T. W. The problem of red mite control on prunes in western New York. Jour. Econ. Ent., 29: pp. 546-550. 1936.

24. Ross, W. A. The status of lubricating oil sprays in Ontario. Ann. Rep. Ent. Soc. Ontario, 62: pp. 49-57. 1932.

25. Sanders, J. G. Observations on the European red mite. Jour. Econ. Ent., 21: p. 314. 1928.

26. Speyer. Obstbaum karbolineum als schadlingsbekampfungsmittel. (Tar distillates as insecticides). Zeit. Angew. Ent., 20: pp. 565-589. 1934. See Rev. Appl. Ent., 22: p. 346. 1935.

27. Steer, W. Use of derris root as an insecticide. Rep. E. Malling Res. Sta., 23: pp. 225-227. 1935.

28. Ward, K. M. Winter treatment of orchard insects. Jour. Dept. Agr. Victoria (Australia), 31: pp. 285-387. 1933.

29. Worthley, H. N. Experiments for control of the rosy aphis and European red mite. Conn. Pom. Soc., Proc. of the 46th Annual Meeting: pp. 48-54. 1936. 




\section{University of Connecticut Libraries}

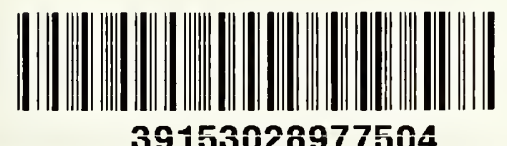


